\title{
Preparing Pupils for Creative Language Production
}

\author{
Dušanka Popović \\ University of Montenegro, Faculty of Philology, Study program for Montenegrin \\ Language and South Slavic Literature
}

\section{Abstract}

The paper presents and analyzes the results of a detailed research of teaching written language production in primary schools in Montenegro. The aim of the research was to determine how, from the perspective of pupils, the process of teaching and learning takes place in primary schools when the creative language production of pupils is concerned. In order for pupils to be successful in the above area, it is important that teachers apply varied and meaningful activities that will prepare pupils for such an act. Therefore, during the research, by using the survey technique and questionnaire, we sought to find out pupils' interest in the subject of mother tongue and literature, discussing how the creative writing activity, i.e. text creation, positions on that list. After that, we tried to determine what activities are particularly suitable for pupils as preparation for written language production and, finally, what actually happens in their classes, that is, whether pupils assess these exercises as useful. The hypotheses have been confirmed because the pupils in the seventh, eighth and ninth grade (third cycle), in different percentages, recognize the presence of a variety of activities offered as a useful preparation for their successful written expression. Based on the analysis of the obtained results, a number of conclusions have been drawn that can be merged into one that reads: in the phase of preparing primary school pupils for written language production, teachers apply different and purposeful activities concerning the themes and structure of written composition.

Key words: creative writing; preparation; teaching; text; writer.

\section{Introduction - Creative Writing and Its Result}

Creation of artistic texts is a topic that has been provoking the interest of philosophers, writers and artists ever since it appeared until present day. The 
complexity of the literary works, their power to enchant the reader, to engage him/ her on all fronts - mentally, emotionally, cognitively, and even physically - encouraged the scientists of various authorities to deal with their emergence. All the more so that the latest research in the field of neuroscience shows that reading can cause actual changes in the brain that can be measured, and that, besides the already known immersion in the world of the novel or character, while reading, something happens at the biological level as well (Berns, 2013). It is not surprising that the scientists around the world, especially at a time when the technological measuring of effects of various factors is possible, notwithstanding the effect of reading, are continually occupied by the power of text creator and the text itself. Where does this inspiration come from, what triggers it, what is the role of talent and what of hard work and learning - are some of the questions that have not been answered with certainty to this day. How can we then teach children and young people this complex activity? What can we offer them? And, above all, how do we prepare them for such an act?

The complexity of writing as a language activity is described by its interdisciplinary foundation, i.e. it being founded in several language disciplines: orthography, grammar, lexicology, and stylistics and text linguistics. The text is a result of cognitive processes, what the writer knows about what he writes, as well as his attitude towards the content he creates (Rosandić, 2002). Although certain level of creativity can be manifested in the process of creating non-artistic texts, creating artistic text is almost impossible without a considerable share of creativity. Therefore, the act of creation of fiction has occupied writers and philosophers from antiquity to the present day, and the explanations of that act have ranged from divine powers and divine inspiration (Plato), through the idea of mimicking the subject world by different means, by which then the individual artistic forms differ - with what techniques and actions the artist achieves his goal (Aristotle), to the sum of the talent, knowledge and skills with special, even divine inspiration, i.e. the combinations of the above-mentioned interpretations through different styles in literature (Baroque, Classicism, Romanticism, Realism, etc.) until the present day.

In the 19th and 20th century, the interest in the very process of the creation of literary work has become even more expressed, and using different ways (interviews, records, letters to loved ones, special books about the process of creation...) writers communicated their inspiration, their hesitation, contemplation, problems they encountered when creating, as well as the ways in which they were resolving the problems in that process. Such materials led to an easier knowledge of their explicit poetics and methods of their work. In historical sequence, it is equally important that the mentioned field has become a specialized discipline within the theory of literature by which it is possible to determine the identity of some work of literary creation and give its interpretation (Vučković, 2008).

Dealing with this issue and its highlighting from different viewpoints led to the view that, in addition to a talent that one carries in him, extensive knowledge and 
erudition, and above all continuous reading of literary works of art, are necessary for the successful creation of a literary artistic text. Part of this paradigm is the possession of theoretical knowledge in the field of literary studies (Vučković, 2016), historiography and other similar materials, as well as other specifics of what (or whom) the creator intends to write. At the very beginning of the book about his own writing Eco points out that the old saying states that the inspiration should be counted for with a small percentage, i.e. a genius is "ten percent inspiration and ninety percent of work" (Eco, 2013, p. 13).

Regardless of the fact that the artistic text is, ultimately, a product of genius supported by talent and knowledge and stimulated by deep inspiration, it is clear that during the process of teaching writing such objectives are neither possible nor desirable to set. An adult who has decided to write about something (being a writer or not!) is run by a certain motivation and inspired by some internal or external factors and needs. In the process of teaching writing, during regular classes, the decision on whether to write, when and what to write is conditioned by curricula and its outcomes, therefore, it somehow comes from the outside. To that extent, the teacher's task to initiate creative forces in each individual in the class is more difficult. That is why preparation for the creation and production of text cannot be accidental, individual or immediate. It has to be planned, continuous, and professionally guided; it must motivate and inspire a group of children or young people to whom it is intended.

Preparation for creative writing begins, in fact, with the act of reading artistic texts - mastering strategies of reading such texts, therefore, by their reception. Human culture is a global system of signs, and the first instance system would be a natural language. Other systems of culture (mythology, religion, art, science) would represent a second level systems. Specificity of the literary artistic text, relative to the first instance sign system, is that it is encoded twice - this means that one code is contained in the natural language expression, and the other is a literary artistic. As twice encrypted, such a text is sent to a slower acceptance by consumers than the plain text, but its informative fullness is increased (Lotman, 2004). The language of literature becomes more complex precisely because of the emergence of sub-codes: to understand the modern novel just a general code of literary language is not enough, nor is the novel code sufficient - it requires a special sub-code of the modern novel and requires special knowledge such as the knowledge of contemporary psychoanalysis and anthropology, so that there are sub-codes for prose, poetry, etc. (Solar, 2012). "Language Arts starts with the attempt to overcome the basic characteristic of the word as an artistic symbol - unmotivated connection between the expression plan and the content plan - and to build linguistic art model, as in the visual arts, based on the iconic principle" (Lotman, 1976, p. 94).

Every record, be it conscious intention of its creator or not, was created to be read by someone. From this perspective, it is inevitable to observe the triad: the writer as the sender of the message, the text as a transmitter and the reader as a 
recipient of information. Given that the basis of any writing is an ambition to achieve communication, information and semiotic sense of the term, creative writing can also be seen in the light of the above mentioned triad. But reading is not just a dialogue between text and reader, it is also an aesthetic act that occurs in their mutual contact, thus achieving the possibility of individual reading and understanding the meaning of the text in the mind of every individual (Iser, 1992).

Besides artistic design of reality and its aesthetic representation, that is, communicating one's views of the world, the aim of the artistic act is to affect the recipient. The author of artwork introduces the reader to co-authorship, drawing him so into his world of reality (Tošović, 2002). Text as a dynamic process and a linguistic event takes place in a sequence of linguistic signs and complete reading where they get their final actualization, so that the act of reception by the reader is almost as active as the act of text production (Lešić, 2008). Knowing that the text which s(he) writes will be read by someone else other than him/herself and the teacher, both in the process of creation, and after completion, opens some new and binding perspectives for small and young artists. This is also the point where teaching of oral and written expression and teaching literature at school closely connect - from a position of reader, one who critically observes, analyzes, contemplates, experiences, enjoys or does not feel comfortable, the pupil becomes the creator of the challenges for future readers! That needs to be thought about when pupils are introduced to writing and when being prepared for this activity, in particular writing based on the model of the literary artistic text.

\section{Preparation for Creative Work - Context}

Successful linguistic production, that is, the creation of oral and written texts is one of the key goals of teaching the mother tongue and literature throughout schooling. Language expression in the subject curriculum intended for teaching the mother tongue and literature at the primary and secondary level (Curriculum for Mother tongue and literature, 2005; Curriculum for Montenegrin language and literature, 2011; Curriculum for Montenegrin-Serbian, Bosnian, Croatian language and literature, 2017) is part of both areas into which the curriculum is divided: language teaching and teaching of literature. Although an integral part of the two wholes, it can be described as an area in which "language skills (activities) of reading, writing, listening and speaking develop and practical forms of language such as describing, retelling, reporting, etc. are learned. The use and the differentiation of functional styles are being practiced" (Bežen, Budinski, \& Kolar Billege, 2012, p. 10). The complex activity of creating is therefore a result of the entire teaching of the subject curriculum on which the knowledge and skills necessary for successful education, but also for successful functioning in the community and society are founded. Whilst the authors used these characteristics to highlight the positive nature of both teaching creatively and teaching for creativity, nevertheless, creeping polarization is possible if teachers take up one position or the other (Jeffrey \& Craft, 2004). 
The creation of both types of text requires knowledge of specifics and appropriateness of style, which corresponds to their lexical, morphological and syntactic structure. In non-artistic texts the prevailing are administrative, journalistic, scientific-popular, scientific and other styles. To create a text modeled upon literary texts, it is important to have the understanding and use the artistic expression with all the peculiarities discussed above. In such a text the idea is not easily noticeable primarily because of the additional code, and the unambiguous meaning of some phrases in the scientific-informational text in the literary work becomes metaphorical and ambiguous (Ingarden, 1971). Understanding the differences in the discourse that are used when creating both types of text is an important step towards successful language production at school.

We have previously highlighted the interdisciplinarity of writing as a linguistic activity, which means that the development of a culture of writing includes knowledge of spelling rules (orthographic standard), knowledge of grammatical norms (the totality of grammatical rules derived from linguistic practices, and normative grammar of the standard language), then the use of linguistic units in a particular functional style (lexical norm), as well as the choice of language resources of neutral, expressive and impressive value - stylistic norm. The culture of writing implies knowledge of the laws of text formatting prescribed by text linguistics, and they include logical and linguistic organization of the messages in a particular type of text (Rosandić, 2002). Pupil's textual product is formed in the process of developing pupil's language skills at the highest (textual) level of integrity of the language message. "It is sometimes an aim, sometimes an outcome, but most frequently, it is the point of the educational process in the teaching of expression and creation according to which (and from which) other stages of the work are shaped and the teaching strategies in certain educational/communication situations are determined" (Gudelj-Velaga, 1990, p. 153).

When writing, a craft and a creative level of writing develops. The craft level refers to the spelling and orthographic accuracy in the writing, to formal and emergent appearance of text (grammatical system and readability), and to the compositional structure of the text, while the creative level refers to the ability and the skill of rearranging and processing information (of the themes and motifs), and to the manner of expression (stylistic peculiarities in the use of words when forming thoughts). Although to some extent it depends on the inclinations and talent, the creative level in pupils can and should be developed, which is why it is especially important to teach children creative writing, not just in the context of additional sections, but as part of regular teaching classes (Visinko, 2010). A very important factor in the creation of the text is a pupil's knowledge of vocabulary, so it is very important to work continuously on its development and improvement.

From the review of literature on writing and the practice observed in schools, it is clear that writers need flexibility to be able to repeatedly return to the same stage of the process and cultivate the habit of writing that is authentic and meaningful. Therefore, teachers should avoid prescribing a strict model of the writing process, and have 
a deep understanding of the research process involved in the very act of creative writing (Sharp, 2016). Also, they need to understand that it is not good to create an environment in the classroom, which requires that every writer follows a mechanical form on which to create his/her own text (Dyson \& Freedman, 2003).

In teaching writing skills, as well as knowledge pertaining to this field, it is necessary to avoid the stereotypical thinking that subject-area teachers require mainly knowledge of subject area and to a very small extent pedagogical and knowledge in teaching methodology, while primary classroom teachers, considering the age of pupils, need a lot more of such knowledge. This attitude reflects a lack of understanding of the role and mission of the teaching methodology and the importance of the teaching competence (Bežen, 2008), and undermines the efforts of teachers to instruct pupils in creative work in a functional and efficient manner.

\section{Review of Teaching Methodology Recommendations}

In teaching practice, there are several different approaches to teaching writing, which may overlap: presentational, interactive, instructional, free and process approach $^{1}$ (Visinko, 2010). The review of literature in the region shows that methodologists deal mostly with exactly the phase of preparation for the very act of creation by proposing concrete practical exercises of different kinds that precede the independent design of a written essay in class.

Čop (1975) makes a distinction between written exercises and semi related exercises and essays. The first group includes transcription and dictation with the aim to improve the individual components of literacy and is more technical in nature. The second group consists of exercises that prepare pupils for all the components of the written composition: processing the contents of the written text and the preparation of the composition thereof, the choice of terms and words, the formulation of the sentences, the preparation for the application of an appropriate style, the fulfillment of grammatical and orthographic demands, as well as the proper regulation of the written composition - its outer side (graphic appearance, tidiness, etc.).

\footnotetext{
${ }^{1}$ The presentational approach is part of the traditional approach to teaching in which the teacher provides instruction for writing on the selected topic, announces the organization of the text, its stylistic characteristics and forms of expression. Within the interactional approach, pupils in small groups work on specified exercise, discuss important stages in the creation, composition and content of the text, and share their thoughts with the group, class and teacher. The instructional approach refers to instruction that takes a longer period of time, and is focused on three main stages in the writing process: planning and organization of the text content, drafting the text, rewriting what has been written and publishing. In the context of free approach, the pupil individually creates a text asking for guidance from teachers and help from peers when $s /$ he estimates that $\mathrm{s} / \mathrm{he}$ needs it. The process writing model was introduced by Dyson (1992), and before him the model was presented by Graves (1982) and Murray (1985). This approach was worked out in a writing workshop of the Project Reading and Writing for Critical Thinking, and it proposes teaching writing through five stages: 1. preparation (making plans and gathering material), 2. writing draft version, 3. correcting 4. editing, 5. publishing (Steel, Meredith, \& Temple, 2002,p. 6). The realization of such a process requires a longer period of time, which in terms of class-time organization of teaching needs careful planning. The objective of teaching the creation of texts is not for all to become writers - but to reach the highest possible level of competence in relation to oneself. The process approach to writing in Montenegro was applied through the project Step by Step, Reading and Writing for Critical Thinking (RWCT) and How to help students to successfully produce oral and written, artistic and non-artistic texts (Popović, 2013).
} 
In a number of occasions, Težak $(1996,1998)$ especially dealt with the area of oral and written expression and in his books discussed different kinds of compositions, the ways of motivation, as well as the very procedures in the creation of the text using a form selected for the expression. Written exercises, as Rosandić (2002) emphasizes, serve to develop writing techniques, adopting graphemic system, the aesthetic design of letters (calligraphy), the acquisition of spelling habits, adopting grammatical norms, enriching vocabulary, the development of style, adopting the rules and laws of text formatting, organizing and finding content, etc.

Nikolić (2010) advocates an opinion that preparing for the written essays is realized continuously through timely and valid previous work in several areas, noting that linguistic skills are acquired and developed by speaking, writing and reading. In the preparation for successful writing he includes continuous lexical and semantic exercises that contribute to enriching pupils' vocabulary.

Gudelj-Velaga (1990) suggests exercises for the development of pupils' vocabulary (lexical exercises and lexical games), followed by exercises with sets of words in a sentence, exercises with sentences and the order of words in a sentence. In the field of style those are exercises related to the meaning and expression of the statements and exercises in creation.

Visinko (2010) proposed exercises related to writing motivated by a literary text: storytelling exercises motivated by literary-theoretical compositions (time and place of the events, characters, plan of the story - the creation of a joint story according to the stimulus; connecting with linguistic skills - arranging a series of words, composing of a story), then exercises of creative storytelling and retelling associated with the features of prose text (distorted story), the exercise of creating shorter and longer discussion texts (problem, critical); exercises for the composition of the text and its parts, as well as exercises of language forms of expression in relation to the type of composition. With isolated exercises, realized at the level of words or phrases, pupils cannot improve the skill of creating a text and therefore all kinds of exercises should be carried out through the writing of a comprehensive text or its parts, which is particularly effective. Therefore, examples of exercises that she states in her book "are dealing with pragmatic unity, that is, with compiling textual units (such as the introduction or the conclusion) of the whole texts" (Visinko, 2010, p. 131).

To create a metatext a group of authors list specific examples of teaching methodology system and its associated factors which describe and propose ways of organizing pupils' independent work, as well as work in groups to solve problems (e.g., highlighting the main characters and main events) for the purpose of text shortening, where the literary work is the starting point for pupils' spoken and written production. The pupil can work independently with a literary work and restructure its components, and find new information relevant to the activity in which s/he participates (Bežen et al., 2012).

Finally, we should not forget the technical aspects of writing which are particularly important for pupils, and to which teachers need to devote the necessary time and 
attention. However, teachers need to be careful not to insist on the technical aspects of writing so that it does not result in children understanding that it is the only thing that they should focus on when writing. Pupils should be reminded to focus and keep in mind other, more important dimensions of this process (Wray, 1993, 2004).

When analyzing the general and specific context in which the preparation for writing happens, or at least existing opportunities, it seems that the craft and creative level of writing, in accordance with individual abilities, can be attained to a greater or lesser extent (as it is in the end affected by talent). Permanent and systematic training will certainly result in all pupils reaching the creative level, because without it there can be no permanent progress in creation of one's own text.

\section{Research Aim}

The study which follows is part of a wider study of written language production of primary school pupils ${ }^{2}$. The results provided in this paper refer to the texts that are created modeling upon literary-artistic texts, i.e. written production in which creativity is dominant. Also, they refer to the pupils as a target group, because we are interested in how they see their teachers' activities in this field and how they see those activities as relevant for themselves.

The goal of the wider research was to determine, from the perspective of pupils, the process of teaching and learning in primary schools with reference to pupils' written production. The research question with which we deal in this work is whether teachers in primary school apply various and meaningful activities in the process of preparing pupils for the production of written language. In relation to the established research problem we have formulated three assumptions: 1) pupils are moderately interested in the activity of creating written texts in the subject Mother tongue and literature; 2) pupils recognize activities which in preparation for creating their own text are most appropriate for them; 3 ) in preparation for creating written texts, teachers implement exercises which pupils estimate as useful.

Data obtained were systematized, quantitatively processed and interpreted trying to determine existing connections and relationships. Systematizing the obtained results, and through statistical analysis, the following conclusions were made.

\footnotetext{
${ }^{2}$ Broader research related to the teaching of written expression in primary schools in Montenegro was implemented during the second semester of the 2015/2016 school year. The aim was to determine the ways of learning and teaching in this area in primary schools, in order to isolate the good sides, but also to suggest ways for its improvement. The questions referred to the ways of motivating pupils to written expression, the starting points for this activity, the choice of themes and titles, the difficulties that pupils encounter, ways they present their written language production, self-rating themselves as creators, as well as on topics that we deal with in this paper. The survey technique and a questionnaire as an instrument were used (structured in 10 questions - two open type and eight multiple-choice questions with the possibility of commenting or adding one's own attitude). The results were used for the analysis of teaching written expression and preparation for teacher training, but have not been published as a whole.
} 


\section{Research Methodology \\ The Research Sample}

The basic research sample (broader definition) comprised all the pupils of the third cycle of primary school in Montenegro. From a broader set we extracted a representative sample consisting of pupils from 14 primary schools from all three regions of Montenegro. From the central region of Montenegro, we incorporated schools from Podgorica (4) and Nikšić (3), from the northern region schools from Bijelo Polje (2), Berane (1) and Rožaje (1) and from the southern region schools from Bar (2) and Budva (1). The selected schools are placed in regional centers, that is, municipalities that have the highest number of schools and pupils. The central region is represented by the largest number of schools in proportion to the number of pupils and schools in that area (51 out of total 163 primary schools in the country). The study included 70 representatives of each grade, a total of 210 pupils, of which $61.42 \%$ female and $38.57 \%$ male respondents. The average age of the pupils was 13 years. In each school, representatives of grades from various classes were selected, as well as pupils of different achievement (excellent, very good, good, satisfactory) in the subject Mother tongue and literature.

Table 1

The basic research sample

\begin{tabular}{llccccccccccc}
\hline City & Region & $\begin{array}{c}\text { Number of } \\
\text { schools }\end{array}$ & \multicolumn{3}{c}{$\begin{array}{c}\text { Grade and number } \\
\text { of pupils }\end{array}$} & M & $F$ & \multicolumn{4}{c}{ Achievement } \\
\hline Podgorica & central & 4 & 20 & 20 & 20 & 23 & 37 & 15 & 15 & 15 & 15 \\
Nikšić & central & 3 & 15 & 15 & 15 & 18 & 27 & 12 & 12 & 12 & 9 \\
Bijelo Polje & northern & 2 & 10 & 10 & 10 & 10 & 20 & 8 & 8 & 8 & 6 \\
Berane & northern & 1 & 5 & 5 & 5 & 7 & 8 & 4 & 4 & 4 & 3 \\
Rožaje & northern & 1 & 5 & 5 & 5 & 6 & 9 & 4 & 4 & 4 & 3 \\
Bar & southern & 2 & 10 & 10 & 10 & 12 & 18 & 8 & 8 & 8 & 6 \\
Budva & southern & 1 & 5 & 5 & 5 & 5 & 10 & 4 & 4 & 4 & 3 \\
& TOTAL: & 14 & 70 & 70 & 70 & 81 & 129 & 55 & 55 & 55 & 45 \\
& & & & 210 & & & & & & & \\
\hline
\end{tabular}

\section{Technique and Instrument}

In the course of the research we used the survey technique and a questionnaire as an instrument, which we delivered to respondents in written form, together with instructions for filling in the questionnaire. The questionnaire of the broader research consisted of ten questions, two of which were open type. Other questions belonged to the category of multiple-choice questions, and five of them offered the possibility of commenting or writing down one's own attitude. This possibility was used by a small number of respondents. 
For the subject of our discussion, we singled out and analyzed the answers to three multiple-choice questions. On the basis of the analysis of the three extracted questions, we tried to determine the extent to which text creation as an activity is attractive to pupils in the third cycle (seventh, eighth and ninth grade), i.e. how they rank it in comparison with other activities taking place in the subject Mother tongue and literature, which of the activities offered are most convenient to pupils in the course of preparing for the creation of a written text, and what activities teachers actually implement in lessons as a preparation for text creation.

\section{Results and Discussion}

Motivation to engage pupils in language and literature lessons, and their reflection on the content being adopted is conditioned, among other things, by the interest in a particular activity. That is why we asked participants which activities they prefer to perform in those lessons. The participants' ranking of the offered categories is shown in Figure 1.

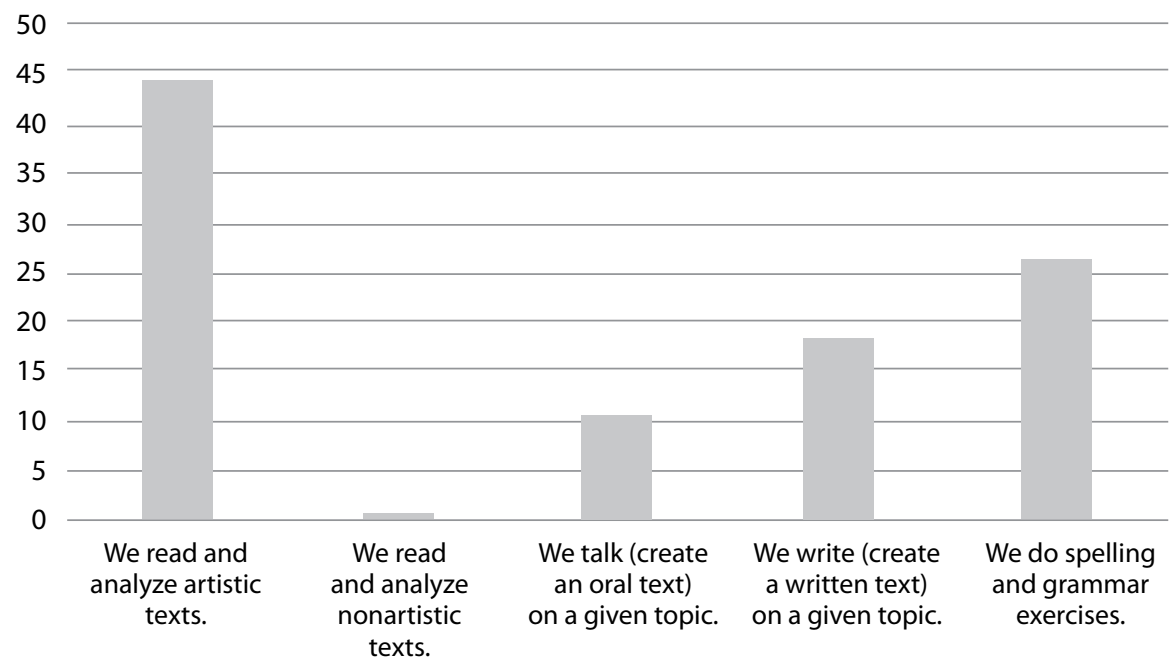

Figure 1. In Mother tongue and literature lessons, l like the most when...

Most of the pupils ranked reading and analysis of literary texts very high (44.44\%). Having in mind the nature of literary and artistic text and its characteristic that, as a layered formation where emotional, fantasy, associative and thought webs are interlaced (Rosandić 2005, p. 215), it evokes the aesthetic experience, and tendency (or habit!) of teachers to deal in more detail with literary and artistic text as, until recently, the only type of text in which, in addition to the traditional analysis, reading strategies were developed, language issues discussed and materials in the field of grammar and spelling were learned - it is not unusual for pupils to have chosen significantly this activity over others. 
Non-artistic texts are ranked as the lowest (0.65\%), although a considerable number of hours should be dedicated to them ${ }^{3}$, in accordance with the current curriculum in Montenegro, with which we want to point out a realistic possibility to help pupils understand and recognize the importance of such use of language as well. This is especially true of science writing which includes interesting topics from the field of natural and social sciences, and develops an important competence of learning through reading. Based on this data, we can assume that the work of the non-artistic texts has not sufficiently taken hold in language teaching, although it is extremely important for the development of reading literacy in its entirety.

Pupils favor the creation of written text (18.30\%), while a smaller percentage opted for the creation of oral text $(10.46 \%)$. The reason for this may be favoring written language production by teachers, even in a situation where the program suggests that each linguistic activity (listening, speaking, reading and writing) should be given $25 \%$ of the total number of hours dedicated to this subject. We assume that teachers make this decision because of the complexity of the written text and an estimation that this type of production takes a lot more time than the verbal. Not only teachers, but also methodologists usually prefer written expression. "That our culture gives more attention to written expression than oral expression, is evident in the fact that the number of papers dealing with written expression far exceeds the number of papers dealing with verbal expression ..." (Ilić, 1998, p. 536).

In relation to the previously observed, we can safely say that there are more reasons for insufficient recognition and understanding of the importance of working with non-artistic texts, as well as the balanced development of all four components of language. These might be important areas that some future research studies need to be directed to.

\footnotetext{
${ }^{3}$ The subject curriculum intended for teaching language and literature consists of two areas: the teaching of language and teaching of literature. In the context of language teaching non-artistic texts of different types are being read, texts modeled upon the read texts (oral and written expression) are being created and grammar and spelling are being studied. Literature teaching includes the reading and interpretation of literary-artistic texts, creation of texts modeled upon the read texts (oral and written expression), and the adoption of literary theory terms (in accordance with age). In the first year, teaching language and literature teaching are given $50 \%$ of the total number of hours, while from the second to ninth grade, language teaching is given $60 \%$ and the teaching of literature $40 \%$ of the number of hours per year. Curricula have clearly stated objectives (Curriculum for Mother tongue and literature, 2005; Curriculum for Montenegrin language and literature, 2011) and outcomes (Curriculum for MontenegrinSerbian, Bosnian, Croatian language and literature, 2017) referring to the steps in developing reading strategies of non-artistic texts and the types of texts that should be studied in a particular grade (e.g., Grade 6, the educational outcome 2: At the end of learning, after listening and reading and analysis of non-artistic texts, the pupil will be able to extract key concepts and related important data, to classify them, compare and complement them, then remember and use them in new situations (learning by reading). Learning outcomes - while learning the pupil will be able to: read, understand and analyze non-artistic texts; determine the basic characteristics of scientific and popular texts, related to the contents of other subject areas (description of life of peers, games, crafts, sports; description of the environment, human life in the past and now, events in nature, plants; description of the development of man and animals; description of objects, products, machinery); to determine the subject matter of the text and its purpose; to give oral and written answers to the teacher's questions about the content of the text; to single out the required data from the text; to extract from the text the key concepts and related important data, and to enter them into prepared conceptual map; concepts: scientific and popular texts related to topics of other subject areas.
} 
In addition to the activities that make up the backbone of the subject offered in the questionnaire, pupils were able to, if they wanted, add some other activity that they found interesting and it concerned this teaching area. This possibility was used by a very small percentage of respondents (0.05\%), and the activities that have been cited, although they may be part of the teaching of mother tongue and literature belong more to multiple sections and extracurricular activities, so that we do not consider them relevant for this research.

Spelling and grammar exercises are another category that a significant percentage of pupils chose as an interesting one (26.14\%). The high positioning of these activities may be due to the fact that the final request for any written work is its grammatical and spelling accuracy.

The next task was related to the choice of one type of preparation that suits the individual pupil best when creating his/her own text. Pupils were offered six activities of which they were to choose one.

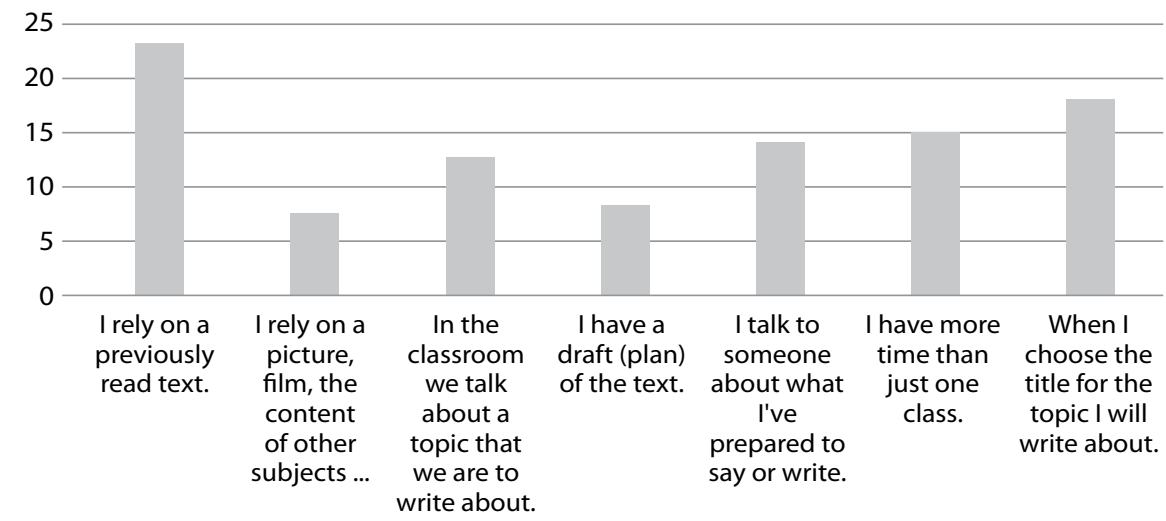

Figure 2. While creating an oral or written text what suits me the most is when ...

The offered responses did not carry the information on the type of the text they refer to, but if we make a connection with the answers to the previous task, we can quite reasonably consider the impact of literary-artistic text on pupils' creativity. Thus, the literary-artistic text as a prototext many times was and is the motivation and support of artistic creation and the starting point of new meanings in intertextual concatenation, the emergence of text and metatext even to experienced writers, and is therefore to be expected that the pupils recognize it as an important starting point and support for new creations (23.38\%).

The text read in the lesson has always been used as a starting point for pupils' language production, both written and oral. There are many ways for the literaryartistic text to be an effective stimulant in the phase of teaching pupils to create their own text, thus teaching creative writing. The way in which the young reader actualizes it as an ambiguous creation is very important, and especially important is the teacher's role in the process of understanding of all its constituents. Teacher leaves space for 
those parts that the pupils have pointed out themselves - as their personal interest and active participation in the process of creating the meaning of text (Grossman, 2010). In addition to understanding the text, also important are summarizing and retelling exercises in order to practice forms of linguistic expression and recognize text structure, i.e. its basic elements (Bežen, Budinski, \& Kolar Billege, 2012).

It is customary that after reading and interpretation of a particular literary work or its part, pupils are offered several titles that relate to the theme of work, its place and specifics in relation to the literary-historical and literary-theoretical context and background. Analyzing the characters and their actions, events and their sequence and connection, as well as the value of the ideas that can be found in the work, opens multiple and interesting starting points for reflection on many important issues and dilemmas. Such texts or its parts therefore can serve as a model for a specific way of expression - description, narration, the dialogue and the like. Getting to know the language of the work or specific style of each creator separately is also very important in understanding the overall impact of literature on pupils' creativity. It is not surprising then that the highest percentage of pupils gave the highest ranking precisely to this possibility of preparing for their own production of a written text.

Unlike text, products of other arts (paintings, movies), and the contents of other subjects as a starting point for creating text, were ranked by pupils as highest in the lowest percentage (7.79\%). It is obvious, however, that even this kind of starting point for the creation is especially inspiring for the shown percentage of pupils, which, when it comes to individualization, is significant.

A significant percentage of pupils (12.99\%) ranked high the possibility of talking about the topic in class while drafting the plan of the text is preferred by only $8.44 \%$ of pupils. Low percentages given for drafting the plan of text does not mean that the pupils consider it unimportant, but that at a certain moment they prefer other activities.

Almost identical percentage of pupils point out the importance of discussion about the first version of the text (14.29\%) and the time that the creators have for creation (14.94\%).

A highly ranked category $(18.18 \%)$ is the ability to choose the topic title, which gives the pupils an opportunity to write about its dimensions of which they have formed the most notions, whether through their own or indirectly acquired experience (Popović \& Novović, 2016).

Pupils did not add a category of their choice to this question.

Once we got information on what suits them best when it comes to writing, we wanted to find out what, in their estimation, is actually happening in the class. Pupils were asked to confirm, deny, or mark as temporary the offered activities of preparing for the writing (Figure 3). According to the pupils' responses, teachers implement all of the given activities, wherein the analysis and the verification of what is written and giving appropriate guidelines (33.86\%) is indicated as the most common. Other 
activities are represented in percentages as follows: creation of text on topics previously discussed (29.61\%), introduction to the composition of the task (21.82\%), exercise aligned with the needs of pupils (24.47\%) and finally joint design of text plan (21.12\%). Although the percentages that show the presence of certain activities in the classroom are not high, a favorable circumstance is that the sum with the category "occasionally" establishes a certain balance in terms of their existence and non-existence.

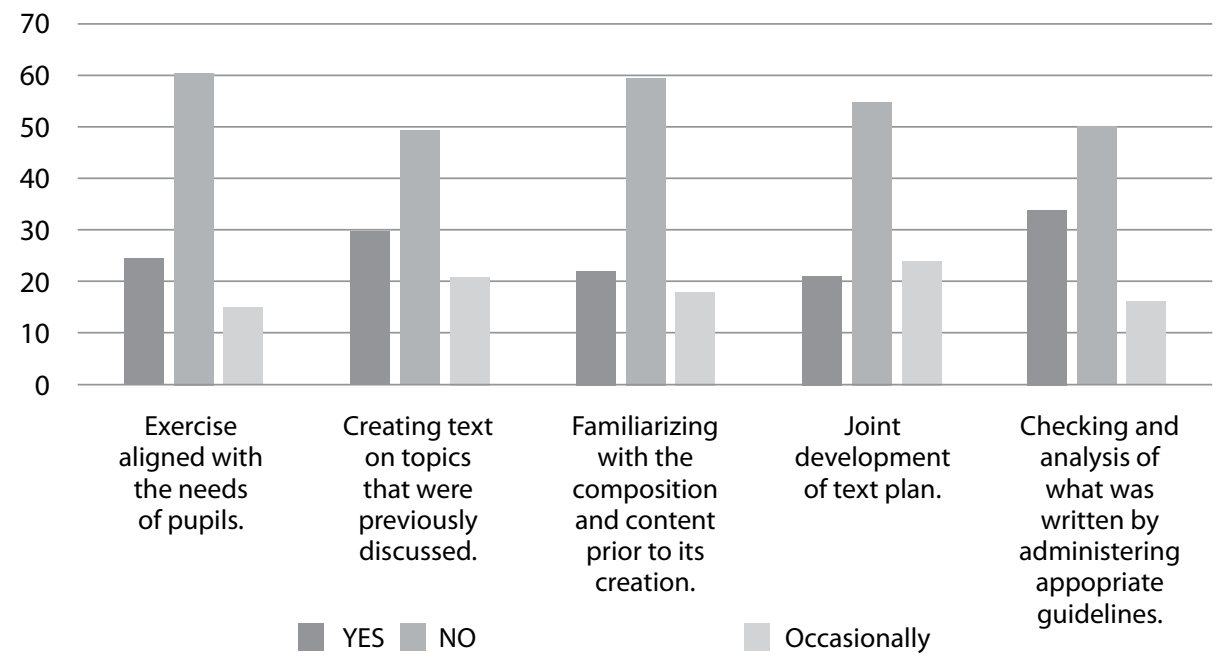

Figure 3. For the creation of a written exercise / assignment the teacher prepares us through...

We felt it was important to ask pupils whether one of the ways to prepare for creating the text is to use exercises, which they estimate to be useful, that is, which are aligned with their needs. The question was of a general type, and it could apply to different types of exercise: language, style and grammar, developing the ability for a different kind of expression, composing the task in accordance with the basic rules and the application of the principles ${ }^{4}$ of text plan creation in accordance with age, proper choice of words and proper formulation of sentences, formation and development of paragraphs and their functional connection within the text body and alike. Pupils estimate that exercises the teachers prepare for them are adapted to their needs in a percentage less than one-third (24.47\%), while the view that they are occasionally adapted is reported by $15 \%$ of pupils. The fact that $60.53 \%$ of them think that there are no such exercises, can mean that they are not applied at all, or we can assume that they are not in accordance with the needs of individuals in different schools and classes. In any case, such a result obliges teachers to thoroughly think about this when teaching language and literature is in question.

\footnotetext{
${ }^{4}$ Three basic principles that must be followed when drafting the text plan: the principle of unity, the principle of progression and the principle of equability (Živković, 2001).
} 
Different motivational techniques are used to introduce pupils to the content of the task or the topic about which they are going to write. Such methods are generally directed to the development of intrinsic motivation for mastering (or expression of) speech content (Gudelj-Velaga, 1990). Conversation on a topic that pupils will write about reveals the material needed for the creation of text and triggers pupils' emotions, or the affective dimension of creation. In the preparatory phase it is important to start from the thoughtful comprising of the theme, that is, considering what the pupil knows related to the topic, what s/he should know and what s/he would want to know, as well as where to find the necessary information and materials, and in which way s/ he would want to write about it (Visinko, 2010). Knowledge of the topic and content, whether it relates to the pupil's personal and social life, nature and the homeland or read literary-artistic text (creating a metatext), is the basic and starting point for the development of pupil's written work.

It is interesting, therefore, that only $29.61 \%$ of pupils reported that in their classroom they practice conversation about a topic before beginning to write about it, $21 \%$ of pupils think that this happens occasionally, while a fairly large percentage (49.39\%) reported that it does not happen in their classrooms. The causes for such pupils' views may be different. It is possible that during the teaching process, prior to writing, the topic was treated within certain activities (e.g., analysis of the literary work dealing with a similar topic), and that immediately before creating it there truly was no discussion about it, respectively, as assessed by the teacher there was no need because through analysis of the work pupils got enough material to work on the topic. Although the percentage of the sum of two preferred categories is $50.61 \%$, the pupils' answers should primarily concern teachers and encourage them to examine their practice, and thus the success of each pupil in text creation.

The fact that referring to the composition of its creation is part of the preparation for the creation of text was confirmed by $21.82 \%$ of pupils, while $59.53 \%$ of them considered that this kind of preparation does not exist, while $18 \%$ reported that the composition of the task is occasionally talked about. Given that the participants belong to the third cycle, it is expected that before any assignment its basic composition does not have to be talked about and the percentage of $18 \%$ of occasional references to the composition could be the real representation of pupils' needs in the eighth and ninth grade. In fact, they have already learned the parts of a text, how they form and mark text sections graphically, what their role and content is and how the passages are shaped and developed as smaller units of a compositional structures and the like. The need for such a reminder $(21.82 \%)$ can be most related to the seventh grade pupils, as the youngest in the group, in addition to the eighth and ninth graders who did not gain specific knowledge at the appropriate level in the previous grades.

However, if we consider that preparation for writing may not only be a direct activity, or one that precedes the very activity of writing - but it can be a continuous exercise, then it is necessary to conduct it regularly, especially in primary school. In 
addition to the basic compositional structure of the text (the introduction, elaboration, conclusion), it is good to also practice rearrangement of materials within these units, particularly the elaboration. Directly related to this is the art of making the text plan with which, in fact, selected material is structured and its rearrangement is planned.

Joint drafting of the text plan as a way of preparation for writing was recognized by $21.12 \%$ of pupils while $54.88 \%$ of them stated that such preparation does not happen in their classes. Of the total sample of participants, $24 \%$ claimed that it happened occasionally. We have focused on the question of drafting a joint plan in order to get as much information about the extent to which this step is left for pupils in the third cycle to engage in on their own. In the process of creating a text, whether the topic is same for all pupils or not, for the age in question, it is logical to expect that each pupil writes an individual plan, i.e. plan for his/her own text. A joint plan is done in the practice phase at an early school age $\left(1^{\text {st }}\right.$ and $2^{\text {nd }}$ cycle). The fact that in the examined sample joint planning of text is happening in the stated percentages may mean that the classes are individualized in accordance with the age and ability of pupils. However, it is always possible and necessary to practice this step in text creation with a particular group of pupils, and that is probably why they recognize it both as permanent and casual way of preparation for writing.

A pupil begins to design one's own text and properly organizes selected material already after the first reading and analysis of texts by renowned authors that $\mathrm{s} / \mathrm{he}$ reads in school, recognizing their composition and creating a plan as a chronological sequence of events. "We apply composition exercises in regular lessons every time we are defining parts of the text we read" (Visinko, 2010, p. 160). Based on the joint plan, pupils can easily make their own, individual, plan for their task. With an individual plan, a pupil expresses an attitude towards the collected material, personal understanding of the topic and his/her own view of its nature. We believe that the exercises of drafting the plan should be carried out continuously at all ages, but insisting on drafting one's own plan (for all ages) is a particularly important step for young creators. Making a plan for other people's texts is a kind of exercise to observe the composition, but also mastering the skills of drafting a plan for one's own text. The aim of such training is that through other people's texts, pupils learn to perceive the order of ideas, their mutual organization and subordination, to recognize the main idea and its development using related information and, to perceive the core of the issue specified by topic.

The essential features of the text, which determine the composition plan to some extent, are its cohesion and coherence. Relationships between elements of the text, grammatical and lexical ties that combine sentences into text provide for text cohesion. The coherence of the text other than the language, points to extra-linguistic circumstances in which a particular statement appears, i.e. what the reader recognizes in the linguistic message and which is necessary for its interpretation (Badurina, 2008).

The structure of the text can be conditioned by its function in the communication act. The function of the text, together with situational and media conditions, determines the structure of the text, i.e. its construction in the thematic and 
grammatical sense. The communicative intent of the sender expressed by means which are conventional in the communication community is the function of the text, because the sender sends specific instructions to the receiver on how the text as a whole should be accepted and understood (Glovacki-Bernardi, 2004).

Assessment and evaluation of pupils' work results in the sum of guidelines for all pupils, because it deals with the analysis and synthesis of successful and less successful sides of each task. This is a very specific activity directly focused on the written linguistic product of each pupil, so it is not surprising that they recognize it and in the highest percentage (33.86\%) point it out as the preparatory activity for a new writing assignment. In the process of valorization and text enhancement, the ability of pupils is raised to a new level of linguistic competence in written language use. Processing includes pupils' understanding that every new attempt is bringing them closer to the goal (Gudelj-Velaga, 1990, p. 160). That is why this item deserves special attention and elaboration in a new paper.

Pupils were given the possibility to indicate some other activities that the teacher creates and uses to prepare them for writing. Judging by their responses, such activities are introduced by a very small percentage $(1.30 \%)$ of teachers. We can assume that pupils do not recognize them, although for the age of students in the third cycle (seventh, eighth and ninth grade) it is unlikely.

In support to school writing which is, however, a planned activity we can indicate also the point of not having to wait for inspiration in order to write. "It is easier to find inspiration while writing than when you are not writing, so you do not necessarily need to be inspired to sit down and start writing" (Novaković, 2007, p. 14). A teacher, who continually applies all of the above exercises even when the writing has, in some way, already begun, can certainly contribute to emerging and developing inspiration.

\section{Conclusions}

By positioning preparatory writing activities through the assessment of their relevance in relation to oneself, by choosing the most convenient ones and, finally, by the assessment to which extent they are actually present in class, we found that the preparation of pupils for the written language production in primary schools mostly happens through different and meaningful activities.

Pupils in the third cycle of primary school are moderately interested in oral and written language production as an activity during Mother tongue and literature lessons. This can be explained by the complexity and the requirements of these activities, and is somewhat expected. For students, oral and written language production is less important than reading and interpretation of literary-artistic texts, and they position this activity high as a special preparation for the creation of their own text. It is clear, therefore, that teachers carry out this activity, but it is necessary to examine how and how much, and in what ways they can be improved by purposefully exploiting pupils' motivation by literary-artistic text. 
Special interest of pupils for grammar and spelling exercises opens up the possibility of continuing work on attaining the standard language in school and its precise usage in oral and written language expression. Although, in accordance with the curriculum, the grammar categories and concepts are taught with non-artistic texts, they can also be identified and analyzed in artistic texts where they are usually given special features of literary-artistic style (expressiveness, allegorical meaning and the like).

As an important factor of creativity, pupils recognize a certain freedom of the author in the sense of expressing their own individuality through choosing a title for topics according to their interests and experiences, as well as the ability to create a text in a time interval longer than one school lesson. Pupils prefer individual over group consultations (in class) on what was written, so it is necessary to provide time and opportunity for such activity. This shows that the methodological guidance by teachers during the creation of a written composition is desirable and important regardless of grade level in primary school.

Pupils in a large percentage state that the creation of texts is not preceded by discussion on the topic they will write about, which can directly affect both the process of creating (inadequate choice of material, non-functional text plan, etc.), and the final product, i.e. text (possible deviation from the topic, inadequate compositional structure, the arrangement of the main and secondary ideas in the text, the choice of motifs and their development, characters, story time and space, etc.). Therefore, teachers should analyze their practices and determine the presence or absence of the aforementioned activity, and prevent the consequences by timely planning functional exercises.

In the process of long-term preparation for writing, it is necessary to include a number of different exercises related to the needs of the group that the teacher is working with, and which are proposed by teaching methodologists.

It is necessary to continuously develop the skill of text composition with the expansion of knowledge about the collection of certain materials, and valuing and selecting the data collected, as well as their organization, depending on the age and individual needs of pupils.

Checking and analyzing what has been written, or the assessment and evaluation of pupils' work is the activity that pupils recognize as the most frequently used in the process of preparation for future writing. Given that pupils receive specific suggestions for their work, it is necessary to apply it during the very process of creation (individual consultations). Checking and analyzing what has been written is an important activity in the process of teaching writing.

The focus of future research can be directed to the forms of preparation for text creation that pupils particularly highlight, in order to determine their specific impact on improving their creative language production. In addition, research should include activities for which pupils claim that they are not implemented in their lessons, having in mind the fact that such activities are basic for acquiring knowledge and skills in the field of oral and written expression of pupils. 


\section{References}

Aristotel (n.d.). Retorika. Zagreb: Naprijed.

Badurina, L. (2008). Između redaka: Studije o tekstu i diskursu. Zagreb: Hrvatska sveučilišna naklada.

Berns, G. S., Blaine, K., Prietula, M. J., \& Pye, B. E. (2013). Short-and long-term effects of a novel on connectivity in the brain. Brain Connectivity, 3(6), 590-600. https://doi. org/10.1089/brain.2013.0166

Bežen, A. (2013). Metodike u suvremenom odgojno-obrazovnom i znanstvenom sustavu. In D. Milanović, A. Bežen, \& V. Domović (Eds.), Metodike u suvremenom odgojno-obrazovnom sustavu (pp. 26-76). Zagreb: Akademija obrazovno-odgojnih znanosti Hrvatske.

Bežen, A., Budinski, V., \& Kolar Billege, M. (2012). Što, zašto, kako u poučavanju hrvatskoga jezika. Metodički praktikum nastave hrvatskoga jezika u nižim razredima osnovne škole. Zagreb: Učiteljski fakultet Sveučilišta u Zagrebu and Profil.

Dyson, A. H., \& Freedman, S. W. (2003). Writing. In J. Flood, D. Lapp, J. R. Squire, \& J. M. Jensen (Eds.), Handbook of research on teaching the English language arts (2nd, ed., pp. 967992). Mahwah, NJ: Lawrence Erlbaum Associates.

Čop, M. (1975). Pismene vježbe i sastavci u mladim razredima osnovne škole, II izdanje. Zagreb: IBG Tiskara „Zagreb“.

Eko, U. (2013). Ispovest mladog romanopisca. Beograd: Službeni glasnik.

Europska Komisija/EACEA/Eurydice (2012). Developing Key Competences at School in Europe: Challenges and Opportunities for Policy. Eurydice Report. Luksemburg: Ured za publikacije Europske unije. Retrieved from http://eacea.ec.europa.eu/education/eurydice/ documents/thematic reports/145HR.pdf

Glovacki-Bernardi, Z. (2004). O tekstu (Second edition). Zagreb: Školska knjiga.

Grosman, M. (2010). U obranu čitanja, čitatelj i književnost u 21. stoljeću. Zagreb: Algoritam, Traduki.

Gudelj-Velaga, Z. (1990). Nastava stvaralačke pismenosti. Zagreb: Školska knjiga.

Ingarden, R. (1971). O saznavanju književnog umjetničkog djela. Beograd: SKZ.

Ilić, P. (1998). Srpski jezik i književnost u nastavnoj teoriji i praksi. Novi Sad: Zmaj.

Iser, W. (1992). Theorie der Literatur - Eine Zeitperspektive. Konstanz: Universitätsverlag Konstanz.

Jeffrey, B., \& Craft, A. (2004). Teaching creatively and teaching for creativity: distinctions and relationships, Educational Studies, 30(1), 77-87.

Lešić, Z. (2008). Teorija književnosti. Beograd: Službeni glasnik.

Lotman, J. M. (1976). Struktura umetničkog teksta. Beograd: Nolit.

Lotman, J. M. (2004). Kultura i eksplozija. [Translated from Russian by Dobrilo Aranitović]. Beograd: Narodna knjiga-Alfa.

Nikolić, M. (2009). Metodika nastave srpskog jezika i književnosti (Fifth edition). Beograd: Zavod za udžbenike.

Novaković, J. (2007). Radionica pisanja fikcije. Zagreb: Algoritam.

Nastavni predemet Maternji jezik i književnost, Predmetni program - srpski, crnogorski, bošnjački i hrvatski jezik i književnost - I, II, III, IV, V, VI, VII, VIII i IX razred osnovne škole [Curriculum 
for Mother tongue and literature - Serbian, Montenegrin, Bosnian and Croatian language and literature]. (2005). Podgorica: Ministarstvo prosvjete i nauke, Zavod za školstvo.

Predmetni program Crnogorski jezik i književnost, I, II, III, IV, V, VI, VII, VIII i IX razred osnovne škole [Curriculum for Montenegrin language and literature]. (2011). Podgorica: Ministarstvo prosvjete i sporta, Zavod za školstvo.

Predmetni program Crnogorski-srpski, bosanski, hrvatski jezik i književnost, I, II, III, IV, V, VI, VII, VIII i IX razred osnovne škole [Curriculum for Montenegrin-Serbian, Bosnian, Croatian language and literature]. (2017). Podgorica: Zavod za školstvo.

Popović, D. (2013). Put stvaraoca ili kako stvarati tekst. In D. Popović (Ed.), Kako učenicima pomoći da uspješno stvaraju usmene i pisane, umjetničke i neumjetničke tekstove - prvi koraci (pp. 10 - 22). Podgorica: Zavod za školstvo.

Popović, D., \& Novović, T. (2016). Teaching Writing Skills - How To Start Writing a Text. Croatian Journal of Education, 18(4), 1235-1273.

Rosandić, D. (2002). Od slova do teksta i metateksta. Zagreb: Profil.

Rosandić, D. (2005). Metodika književnog odgoja. Zagreb: Školska knjiga.

Sharp, L. A. (2016). Acts of Writing: A Compilation of Six Models that Define the Processes of Writing. International Journal of Instruction, 9(2), 77-90. https://doi.org/10.12973/ iji.2016.926a

Solar, M. (2012). Teorija književnosti sa rječnikom književnoga nazivlja. Beograd: Službeni glasnik.

Težak, S. (1996). Teorija i praksa nastave hrvatskoga jezika 1. Zagreb: Školska knjiga.

Težak, S. (1998). Teorija i praksa nastave hrvatskoga jezika 2. Zagreb: Školska knjiga.

Tošović, B. (2002). Funkcionalni stilovi. Graz: Instutut fur Slawistik der Karl-FranzensUniversität.

Visinko, K. (2010). Jezično izražavanje u nastavi hrvatskog jezika. Pisanje. Zagreb: Školska knjiga.

Vučković, R. (2008). Pisac, delo, čitalac. Beograd: Službeni glasnik.

Vučković, D. (2016). Montenegrin Teachers' Perception of the Acquisition of Literary Terms in Primary School. Croatian Journal of Education, 18(2), 419-446. https://doi.org/10.15516/ cje.v18i2.1601

Wray, D. (1993). What do children think about writing? Educational review, 45(1), 67-77.

Živković, D. (2001). Teorija književnosti sa teorijom pismenosti, priručnik za nastavnike i učenike. Beograd: IK Draganić.

\section{Dušanka Popović}

University of Montenegro, Faculty of Philology,

Department for Montenegrin Language and South Slavic Literature

Danila Bojovića b.b., 81400 Nikšić, Montenegro

dusana@t-com.me 


\section{Priprema učenika za kreativnu jezičnu proizvodnju}

\section{Sažetak}

U tekstu se iznosi $i$ analizira dio rezultata obimnijeg istraživanja nastave pisanog izražavanja u osnovnim školama u Crnoj Gori, čiji je cilj bio utvrditi kako se, iz perspektive učenika, u osnovnim školama odvija proces poučavanja i učenja s obzirom na učeničku kreativnu jezičnu proizvodnju. Da bi učenici u njoj bili uspješni, važno je da učitelji primjenjuju raznovrsne i svrsishodne aktivnosti koje će ih za taj čin pripremiti. Zato smo, tijekom istraživanja, koristeći se tehnikom anketiranja i anketnim upitnikom, nastojali saznati što učenike posebno zanima na satima materinskoga jezika i književnosti, razmatrajući gdje se na tom popisu nalazi aktivnost kreativnog pisanja, tj. stvaranja teksta. Nakon toga smo nastojali utvrditi koje aktivnosti učenicima posebno odgovaraju kao priprema za pisanu jezičnu proizvodnju i, na kraju, što se zaista, s tom svrhom, dogada u njihovim razredima, tj. procjenjuju li te vježbe učenici kao korisne. Postavljene su hipoteze potvrđene jer učenici sedmog, osmog $i$ devetog razreda (treći ciklus), u različitim postotcima, prepoznaju prisustvo raznovrsnih aktivnosti koje su ponuđene kao korisna priprema za njihovo uspješno pisano stvaralaštvo. Na osnovi analize dobivenih rezultata izvedeno je više zaključaka koje možemo ujediniti u zaključak: učitelji u fazi pripreme za pisanu jezičnu proizvodnju učenika u osnovnoj školi primjenjuju različite $i$ svrsishodne aktivnosti koje se tiču tematike i strukture pisanoga sastava.

Ključne riječi: kreativno pisanje; nastava; priprema; stvaratelj; tekst.

\section{Uvod - kreativno pisanje}

Stvaranje umjetničkih tekstova tema je koja izaziva zanimanje filozofa, pisaca i umjetnika od antičkih vremena do danas. Kompleksnost književnih djela, njihova moć da opčine čitatelja, da ga angažiraju na svim poljima - misaono, emotivno, kognitivno, pa i tjelesno - poticala je znanstvenike različitih područja da se bave njihovim nastankom. Najnovija istraživanja u području neuroznanosti pokazuju da čitanje može izazvati stvarne promjene u mozgu, da je te promjene moguće mjeriti, kao i da se, osim do sada poznatog uživljavanja u svijet romana ili lika, tijekom čitanja nešto događa i na biološkoj razini (Berns, 2013). Zbog toga ne iznenađuje što je i znanstvenike širom svijeta, posebno u vremenu u kojem je tehnološki moguće 
mjeriti utjecaje različitih činitelja, pa i čitanja, nastavila zaokupljati moć stvaratelja teksta i teksta samog. Odakle to nadahnuće dolazi, čime je potaknuto, koja je uloga talenta, a koja upornog rada i učenja - ni danas se pouzdano ne zna. Kako, stoga, toj kompleksnoj aktivnosti poučavati djecu i mlade? Što im pružiti? I kako ih, nadasve, pripremiti za taj čin?

O kompleksnosti pisanja kao jezične djelatnosti govori njegovo interdisciplinarno utemeljenje, tj. njegova utemeljenost u više jezičnih disciplina: ortografiji, gramatici, leksikologiji, stilistici i lingvistici teksta. Tekst je rezultat spoznajnih procesa, onoga što pisac o predmetu o kojem piše zna, kao i njegova odnosa prema sadržaju koji stvara (Rosandić, 2002). Iako je određenu razinu kreativnosti moguće postići i u procesu stvaranja neumjetničkih tekstova, stvoriti umjetnički tekst gotovo je nemoguće bez znatnog udjela kreativnosti. Zato je čin stvaranja fikcije zaokupio pisce i filozofe od antike do danas, a objašnjenja tog čina kretala su se od djelovanja božanskih sila i božanskog nadahnuća (Platon), preko ideje o umjetnosti kao podražavanju predmetnog svijeta različitim sredstvima, po kojima se onda pojedine umjetničke vrste i razlikuju - tehnikom i rješenjima kojima umjetnik postiže cilj (Aristotel), ukupnošću talenta, znanja i vještina, pa i božanskog nadahnuća, tj. kombinacijama prethodno navedenih tumačenja različitih književnih pravaca (barok, klasicizam i racionalizam, romantizam, realizam i dr.).

U XIX. i XX. stoljeću interes za proces nastanka djela postao je izraženiji, pa su pisci na različite načine (intervjui, zabilješke, pisma dragim osobama, posebne knjige o stvaranju...) priopćavali svoje inspiracije, kolebanja, promišljanja, probleme na koje su nailazili tijekom stvaranja, kao i načine na koje su ih rješavali. Takva građa vodila je do lakše spoznaje njihove eksplicitne poetike i metoda njihova rada. U povijesnom slijedu važno je i to što je navedeno područje postalo posebna disciplina u okviru teorije književnosti kojom je moguće utvrđivati identitet netkog djela i dati njegovo tumačenje (Vučković, 2008).

Bavljenje tom problematikom i njezinim osvjetljavanjem $\mathrm{s}$ različitih stajališta dovelo je do stava da su osim talenta za uspješno stvaranje književnoumjetničkog teksta neophodni široko znanje i erudicija, a prije svega kontinuirano čitanje umjetničkih djela. Dio te paradigme jest i posjedovanje teorijskih znanja iz područja znanosti o književnosti i književnoteorijskih pojmova (Vučković, 2016), zatim o povijesnoj i drugoj sličnoj građi, kao i o ostalim posebnostima onoga o čemu (ili o kome) stvaratelj namjerava pisati. Na samom početku knjige o vlastitom pisanju Eko ističe da stara izreka kaže kako inspiraciji pripada malen postotak piščeva nadahnuća, tj. da je genije „deset odsto nadahnuća i devedeset odsto rada” (Eko, 2013, str. 13).

Koliko god umjetnički tekst bio, u konačnici, proizvod genijalnog uma podržanog talentom i znanjem, i potaknutog dubokom inspiracijom, jasno je da tijekom procesa poučavanja pisanja takve ciljeve niti je moguće, a niti poželjno postavljati. Odrasla osoba koja je odlučila o nečemu pisati (bila ta osoba pisac ili ne) uvijek je pokrenuta izvjesnom motivacijom i inspirirana nekim unutarnjim ili vanjskim čimbenicima i 
potrebama. U procesu poučavanja pisanja, tijekom redovne nastave, odluku o tome da treba pisati, kada i o čemu - donosi učitelj ${ }^{5}$ uvjetovan predmetnim programom i njegovim ishodima, dakle, netko izvana. Zato je njegov zadatak da pokrene stvaralačke snage u svakom pojedincu u razredu mnogo teži, a priprema za kreaciju i proizvodnju teksta ne može biti slučajna, pojedinačna i trenutačna. Ona mora biti planirana, kontinuirana, stručno vođena, mora motivirati i inspirirati grupu djece ili mladih ljudi kojoj je namijenjena.

Priprema za kreativno pisanje počinje, zapravo, čitanjem umjetničkih tekstova savladavanjem strategija čitanja takvog teksta, dakle, njihovom recepcijom. Čovjekova kultura predstavlja globalni znakovni sustav, a prvostupanjski sustav bio bi prirodni jezik. Ostali sustavi kulture (mitologije, religije, umjetnosti, znanosti) predstavljali bi drugostupanjske sustave. Specifičnost književnoumjetničkog teksta u odnosu na prvostupanjski znakovni sustav sastoji se u tome što je dva puta kodiran - to znači da je jedan kod sadržan u prirodnom jezičnom izrazu, a drugi je književnoumjetnički. Dva puta kodiran, takav je tekst upućen na usporenije prihvaćanje od konzumenta od običnog teksta, ali je zato njegova informativna punoća veća (Lotman, 2004). Jezik književnosti postaje sve složeniji upravo zbog nastajanja potkodova: za razumijevanje modernog romana nije dovoljan samo opći kod jezika književnosti, a ni samo kod romana - potreban je specijalni potkod modernog romana i potrebna su specijalna znanja kakva su znanja suvremene psihoanalize i antropologije, pa postoje potkodovi za prozu, za poeziju i slično (Solar, 2012). „Jezička umetnost počinje od pokušaja da se prevlada osnovno svojstvo reči kao umetničkog znaka - nemotivisana veza između plana izraza i plana sadržaja - i izgradi jezički umetnički model, kao u likovnim umetnostima, na ikoničkom principu" (Lotman, 1976, str. 94).

Svaki zapis, bila to svjesna namjera njegova tvorca ili ne, nastao je da bi ga netko pročitao. $S$ tog stajališta neizbježno je promatrati trijadu: pisca kao pošiljatelja poruke, teksta kao prijenosnika i čitatelja kao primatelja informacije. S obzirom na to da je u osnovi svakog pisanja namjera da se ostvari komunikacija, u informacijskosemiotičkom smislu pojam kreativno pisanje također možemo promatrati u svjetlu prethodno navedene trijade. No, čitanje nije samo dijalog između teksta i čitatelja, to je i estetski čin koji nastaje u njihovu međusobnom kontaktu, ostvarujući tako mogućnost individualnoga čitanja i razumijevanja smisla teksta u svijesti svakog pojedinca (Iser, 1992).

Osim umjetničkoga oblikovanja stvarnosti i njezina estetskoga predstavljanja, tj. priopćavanja vlastitih pogleda na svijet, cilj je umjetničkoga čina i djelovanje na recipijenta. Autor umjetničkoga djela uvodi čitatelja u suautorstvo, uvlačeći ga tako u svoj svijet realnosti (Tošović, 2002). Tekst se, kao dinamički proces i jezično zbivanje, odvija u slijedu u kojem se nižu jezični znakovi i ispunjava u čitanju u kojem dobiva

\footnotetext{
${ }^{5}$ Naziv „učitelj“ u tekstu odnosi se na učitelje razredne nastave i učitelje materinskoga jezika i književnosti u predmetnoj nastavi.
} 
svoju krajnju aktualizaciju, pa je čin recepcije koji obavlja čitatelj gotovo jednako aktivan kao i čin njegove proizvodnje (Lešić, 2008). Spoznaja da će tekst koji piše čitati još netko osim njega samog i učitelja, kako u procesu stvaranja tako i nakon završetka, otvara neke nove i obavezujuće perspektive kod malih i mladih stvaratelja. To je, također, točka gdje se nastava usmenog i pisanog izražavanja i nastava književnosti u školi tijesno dodiruju - iz pozicije čitatelja, onog koji kritički promatra, analizira, promišlja, doživljava, uživa ili mu nije lagodno, učenik postaje kreator izazova za buduće čitatelje! I o tome treba misliti kada se učenici uvode u područje pisanja i kada se pripremaju za tu aktivnost, posebno po ugledu na književnoumjetnički tekst.

\section{Priprema za kreativno stvaranje - kontekst}

Uspješna jezična proizvodnja, tj. stvaranje usmenih i pisanih tekstova, jedan je od ključnih ciljeva nastave materinskoga jezika i književnosti tijekom cijelog školovanja. Jezično izražavanje u predmetnom programu namijenjenom nastavi materinskoga jezika i književnosti na osnovnoškolskoj i srednjoškolskoj razini (Nastavni predmet Maternji jezik i književnost, 2005; Predmetni program Crnogorski jezik i književnost, 2011; Predmetni program Crnogorski-srpski, bosanski, hrvatski jezik i književnost, 2017) dio je oba područja na koja se program kao cjelina dijeli: na nastavu jezika i nastavu književnosti. Iako čini sastavni dio dviju cjelina, može se opisati kao područje u kojem se „razvijaju jezične djelatnosti (aktivnosti) čitanja, pisanja, slušanja i govorenja i uče praktični oblici jezika kao što su npr. opisivanje, prepričavanje, izvještavanje itd. Uvježbava se uporaba i razlikovanje funkcionalnih stilova" (Bežen, Budinski, Kolar Billege, 2012, str. 10). Kompleksna aktivnost stvaranja rezultat je, dakle, cjelokupne nastave predmeta kojim se utemeljuju znanja i vještine neophodne za uspješno obrazovanje, ali i uspješno djelovanje u zajednici i društvu. Prilikom poučavanja kreativnog pisanja učitelji trebaju biti svjesni razlike između kreativnog poučavanja i poučavanja kreativnosti, promišljajući i primjenjujući i jedno i drugo, kako ne bi došlo do potpune polarizacije (Jeffrey, Craft, 2004).

Za stvaranje i jedne i druge vrste teksta neophodno je poznavanje posebnosti i primjerenosti stila koji im svojom leksičkom, morfološkom i sintaktičkom strukturom odgovara. U neumjetničkim tekstovima prevladavaju administrativni, publicistički, znanstveno-popularni, znanstveni i dr. stilovi, a za stvaranje teksta po ugledu na književnoumjetnički stil važno je razumijevanje i upotreba umjetničkoga izraza sa svim posebnostima o kojima smo prethodno govorili. U takvom tekstu ideja nije lako uočljiva ni prepoznatljiva upravo zahvaljujući dodatnom kodu, pa nedvosmisleno značenje pojedinih rečenica u znanstveno-informativnom tekstu, u književnoumjetničkom djelu postaje metaforično i dvoznačno (Ingarden, 1971). Razumijevanje razlike u diskursu koji se koristi prilikom kreiranja jedne i druge vrste teksta važan je korak prema uspješnoj jezičnoj proizvodnji u školi.

Prethodno smo istaknuli interdisciplinarnost pisanja kao jezične aktivnosti, što znači da razvoj kulture pisanja obuhvaća poznavanje pravopisnih pravila (pravopisnu 
normu), poznavanje gramatičke norme (ukupnost gramatičkih pravila izvedenih iz jezične prakse i normativne gramatike standardnog jezika), zatim uporabu jezičnih jedinica u određenom funkcionalnom stilu (leksičku normu), kao i mogućnost izbora jezičnih sredstava neutralne, ekspresivne i impresivne vrijednosti - stilističku normu. Kultura pisanja podrazumijeva poznavanje zakonitosti oblikovanja teksta koje propisuje tekstna lingvistika, a one obuhvaćaju logičku i jezičnu organizaciju poruka u određenoj vrsti teksta (Rosandić, 2002). Učenički sastavak nastaje u procesu razvijanja učeničkih jezičnih sposobnosti na najvišoj (tekstovnoj) razini cjelovitosti govorne poruke.„On je ponekad cilj, ponekad ishodište, ali najčešće točka odgojno-obrazovnog procesa u nastavi izražavanja i stvaranja prema kojoj (i iz koje) se uobličavaju ostale etape rada i određuju nastavne strategije u pojedinim nastavnim/komunikacijskim situacijama" (Gudelj-Velaga, 1990, str. 153).

Prilikom pisanja razvija se zanatska i stvaralačka razina pisanja - zanatska razina odnosi se na pravopisnu i slovničku točnost $\mathrm{u}$ pisanju, na formalno-pojavni izgled teksta (slovni sustav i čitkost) i na kompozicijsko ustrojstvo teksta, a stvaralačka se razina odnosi na sposobnost i vještinu prerade i obrade podataka (teme i motiva), na način izražavanja (stilske osobitosti u uporabi riječi i u oblikovanju misli). Iako donekle ovisi o sklonosti i darovitosti, stvaralačka se razina kod učenika može i treba razvijati, pa je zato posebno važno poučavati djecu kreativnom pisanju, osim u okviru sekcija, i u redovitoj nastavi (Visinko, 2010). Veoma važan činitelj u procesu stvaranja teksta jest i rječnik kojim učenik raspolaže, pa je na njegovu razvoju i unapređenju neophodno kontinuirano raditi.

Uvidom u literaturu o pisanju i praksu koja se u školama provodi, jasno je da je piscima neophodna fleksibilnost kako bi se više puta mogli vraćati na istu fazu procesa pisanja i tako njegovati navike pisanja koje su autentične i smislene. Zato učitelji trebaju izbjegavati propisivanje strogoga modela, kao i razumjeti istraživačke procese koji su uključeni u sam čin stvaralačkog pisanja (Sharp, 2016). Također, trebaju razumjeti da nije dobro kreirati ambijent u učionici koji zahtijeva da svaki pisac prati neki mehanički obrazac na osnovi kojeg će stvarati vlastiti tekst (Dyson i Freedman, 2003).

U poučavanju vještini pisanja, kao i znanjima koja se tiču tog područja, nužno je izbjegavati stereotipna mišljenja da su učiteljima u predmetnoj nastavi potrebna uglavnom znanja matične znanosti i u vrlo maloj mjeri pedagoška i metodička znanja, a da su učiteljima u razrednoj nastavi, s obzirom na uzrast učenika, takva znanja mnogo potrebnija. Takav stav odražava neshvaćanje uloge i misije metodike i važnosti metodičke osposobljenosti u poučavanju (Bežen, 2008), te sprečava napore učitelja da učenike upute u stvaralaštvo na funkcionalan i djelotvoran način.

\section{Pregled metodičkih preporuka}

U nastavnoj praksi koristi se nekoliko različitih pristupa poučavanja pisanja, koji se mogu isprepletati: prezentacijski, interakcijski, instrukcijski, slobodni i procesni pristup ${ }^{6}$ 
(Visinko, 2010). Pregled literature u zemljama u regiji pokazuje da su se metodičari najviše bavili upravo fazom pripreme za čin stvaranja, predlažući konkretne praktične vježbe različitih vrsta koje prethode samostalnoj izradi pisanog sastavka u razredu.

Čop dijeli pisane vježbe na vezane i poluvezane vježbe i sastavke. Prvoj grupi pripadaju prepisivanje i diktati čiji je zadatak unapređivanje pojedinih komponenti pismenosti i više su tehničke prirode. Drugu grupu čine vježbe koje pripremaju učenike za sve komponente pisanog sastavka: obradu sadržaja sastavka i izradu njegove kompozicije, izbor izraza i riječi, oblikovanje rečenica, pripremu za primjenu odgovarajućeg stila, ispunjavanje gramatičko-pravopisnih zahtjeva, kao i korektno uređenje sastavka - njegova vanjska strana (grafički izgled, urednost i sl.) (Čop, 1975).

Područjem usmenog i pisanog izražavanja u više se navrata posebno bavio Težak (1996, 1998) koji u svojim knjigama razmatra vrste sastavaka, načine motivacije, kao i postupke u stvaranju teksta odabranim oblikom izražavanja. Pisane vježbe, ističe Rosandić (2002), služe razvijanju tehnike pisanja, usvajanju grafemskoga sustava, estetskom oblikovanju slova (krasopis), stjecanju pravopisnih navika, usvajanju gramatičke norme, bogaćenju rječnika, razvijanju stila, usvajanju pravila o zakonitostima oblikovanja teksta, organiziranju sadržaja, pronalaženju sadržaja...

Nikolić se zalaže za to da se priprema za pisane sastavke ostvaruje kontinuirano, pravodobnim i valjanim prethodnim radom na više područja, ističući da se jezično umijeće stječe i razvija govorenjem, pisanjem i čitanjem. U pripremu za uspješno pisanje on ubraja kontinuirane leksičke i semantičke vježbe kojima se bogati rječnik učenika, zatim pravopisne i stilske vježbe koje doprinose funkcionaloj primjeni pravopisnih znanja, razumijevanju i razvoju vlastitog stila i sl. (Nikolić, 2010).

Gudelj-Velaga predlaže vježbe za razvoj učeničkog rječnika (leksičke vježbe i leksičke igre), zatim vježbe sa skupovima riječi u rečenici, vježbe s rečenicama i s redom riječi u rečenici. U području stila to su vježbe u vezi sa značenjem i izražajnošću izraza i vježbe u stvaralaštvu (Gudelj-Velaga, 1990).

Visinko predlaže vježbe u odnosu na pisanje motivirano književnim tekstom: vježbe pripovijedanja motivirane književnoteorijskim sastavnicama (vrijeme i mjesto događaja, likovi, plan priče - stvaranje zajedničke priče prema poticaju;

\footnotetext{
${ }^{6}$ Prezentacijski pristup dio je tradicionalne nastave u kojoj učitelj daje upute za pisanje o odabranoj temi, priopćuje ustrojstvo teksta, njegove stilističke karakteristike i oblik izražavanja. $U$ okviru interakcijskog pristupa učenici u manjim grupama vježbaju, raspravljaju o važnim fazama u stvaranju, o kompoziciji i sadržaju teksta, a svoja promišljanja dijele s grupom, odjelom i učiteljem. Instrukcijski pristup odnosi se na poučavanje koje traje duže vremena i usmjereno je na tri glavne faze u procesu pisanja: planiranje i organizacija sadržaja teksta, sastavljanje teksta, prepravljanje napisanog. U okviru slobodnog pristupa učenik samostalno stvara tekst tražeći upute od nastavnika i pomoć od suučenika kada procijeni da mu je potrebno. Model procesnog pisanja uveo je A. H. Dyson (1992), a prije su ga zastupali D. H. Graves (1982) i D. M. Murray (1985). Pristup je razrađen u okviru radionice za pisanje u projektu Čitanje i pisanje za kritičko mišljenje i njime se predlaže poučavanje pisanja u pet faza: 1 . priprema (izrada plana i sakupljanje građe), 2. izrada radne verzije, 3. popravljanje 4. uređivanje, 5. objavljivanje (Steel, Meredith, Temple, 2002). Za realizaciju takvog procesa potrebno je duže razdoblje koje je u uvjetima razredno-satne organizacije nastave potrebno brižljivo planirati. Cilj poučavanja oblikovanja tekstova i nije da svi postanu pisci - već da dosegnu najvišu moguću razinu te kompetencije u odnosu na same sebe. Procesni pristup pisanju u Crnoj Gori primjenjivao se u projektima Korak po korak, Razvoj kritičkog mišljenja (RWCT) i Kako učenicima pomoći da uspješno stvaraju usmene i pisane, umjetničke i neumjetničke tekstove (Popović, 2013).
} 
povezivanje s jezičnim znanjima - sređivanje niza riječi, sastavljanje priče), zatim vježbe stvaralačkoga pričanja i prepričavanja povezane s obilježjima proznoga teksta (iskrivljena priča), vježbe sastavljanja kraćih i dužih raspravljačkih tekstova (problemskih, kritičkih); vježbe za kompoziciju teksta i njezine dijelove, kao i vježbe oblika jezičnog izražavanja u odnosu na vrste sastava. Izoliranim vježbama ostvarenima na razini riječi ili rečenice učenici ne unapređuju vještinu stvaranja teksta i zato sve vrste vježbi treba provoditi pisanjem cjelovitoga teksta ili njegovih dijelova, što je posebno učinkovito. Zato se primjeri vježbi koje navodi u svojoj knjizi „bave nadrečeničnim jedinstvom, tj. sastavljanjem tekstualnih cjelina (kao što je npr. uvod ili zavšetak) cjelovitih tekstova" (Visinko, 2010, str. 131).

Za stvaranje metateksta grupa autora navodi konkretne primjere metodičkog sustava i njemu pripadajućih činitelja u okviru kojih se opisuju i predlažu načini organizacije samostalnog rada učenika, kao i rada u skupini u rješavanju problema (npr. isticanje glavnih likova i glavnih događaja) sa svrhom sažimanja teksta, pri čemu je književno djelo polazište za govorenu i pisanu učeničku proizvodnju. Učenik se za vrijeme rada samostalno snalazi u književnom djelu i restrukturira njegove elemente, te pronalazi nove podatke važne za aktivnost u kojoj sudjeluje (Bežen i sur., 2012).

$\mathrm{Na}$ kraju, ne treba zaboraviti ni tehničke aspekte pisanja koji su za učenike posebno važni, pa im učitelji trebaju posvetiti potrebno vrijeme i pozornost. Treba, međutim, biti obazriv da inzistiranje na tehničkim aspektima pisanja ne bi rezultiralo time da djeca shvate da je to jedino na što se, prilikom pisanja, treba usredotočiti. Učenike treba podsjećati i usmjeravati na to da imaju na umu i druge, mnogo važnije dimenzije tog procesa (Wray, 1993, 2004).

Kada se analizira kontekst u kojem se odvijaju pripreme za pisanje, ili bar mogućnosti koje za to postoje, čini se da je i zanatsku i stvaralačku razinu pisanja, u skladu s individualnim sposobnostima, moguće dostići u manjoj ili većoj mjeri (na što u konačnici utječe i darovitost). Stalna i sustavna vježbanja sigurno će doprinijeti tome da svi učenici dosegnu stvaralačku razinu, jer bez njih ne može biti ni stalnog napredovanja u izradi vlastitog teksta.

\section{Cilj istraživanja}

Istraživanje koje slijedi dio je obimnijeg istraživanja o pisanoj jezičnoj proizvodnji učenika osnovnih škola u Crnoj Gori

\footnotetext{
${ }^{7}$ Šire istraživanje odnosilo se na nastavu pisanog izražavanja u osnovnim školama u Crnoj Gori i ostvareno je tijekom drugog polugodišta školske 2015./2016. godine. Cilj je bio da se utvrde načini učenja i poučavanja u tom području u osnovnim školama, kako bi se izdvojile dobre strane, ali i predložili načini za njezino unapređenje. Pitanja su se odnosila na načine motiviranja učenika za pisano stvaralaštvo, polazišta za tu aktivnost, izbor teme i naslova, teškoće na koje učenici nailaze, načine na koje predstavljaju svoju pisanu jezičnu proizvodnju, samoprocjenu sebe kao stvaratelja, kao i na tematiku kojom se u ovom radu bavimo. Koristila se tehnika anketiranja, a od instrumenata anketni upitnik koji je bio strukturiran od 10 pitanja (dva otvorenog tipa i osam pitanja višestrukog izbora; kod pet pitanja moguće je bilo dopisati vlastiti stav). Rezultati su se koristili za analizu nastave pisanog izražavanja i pripremu edukacije nastavnika i nisu objavljeni u cjelini.
} 
Istraživačko pitanje kojim se u ovom radu bavimo glasi: primjenjuju li u procesu pripreme za pisanu jezičnu proizvodnju učenika učitelji u osnovnoj školi različite i svrsishodne aktivnosti? U odnosu na utvrđeni istraživački problem oblikovali smo tri pretpostavke: učenici su umjereno zainteresirani za aktivnost stvaranja pisanih tekstova na satima materinskoga jezika i književnosti; učenici prepoznaju aktivnosti koje im tijekom pripreme za stvaranje vlastitog teksta najviše odgovaraju; tijekom pripreme za stvaranje teksta učitelji ostvaruju vježbanja koja učenici procjenjuju kao korisna.

Dobivene podatke smo usustavili, kvantitivno obradili i interpretirali nastojeći utvrditi veze i odnose koji među njima postoje. Usustavljivanjem dobivenih odgovora i njihovom statističkom obradom izvedeni su određeni zaključci. Slična istraživanja, na čije bismo se rezultate mogli pozvati i usporediti ih s dobivenima, u Crnoj Gori nisu provedena.

\section{Metodologija istraživanja Istraživački uzorak}

Osnovni skup istraživanja (šire definiran) činili su svi učenici trećeg ciklusa osnovne škole (sedmi, osmi i deveti razred) u Crnoj Gori. Iz šireg skupa izdvojili smo reprezentativni uzorak koji čine učenici trećeg ciklusa iz 14 osnovnih škola, iz sve tri regije u Crnoj Gori. Iz središnje regije obuhvatili smo škole iz Podgorice (4) i Nikšića (3), iz sjeverne regije to su škole iz Bijelog Polja (2), Berana (1) i Rožaja (1) i iz južne regije škole iz Bara (2) i Budve (1). Odabrane škole predstavnice su regionalnih centara, odnosno općina koje imaju najveći broj škola i učenika. Središnja regija zastupljena je s najvećim brojem škola proporcionalno broju učenika i škola u tom području (51 od ukupno 163 osnovne škole u zemlji). $U$ istraživanju je sudjelovalo po 70 predstavnika sedmog, osmog i devetog razreda, ukupno 210 učenika, od kojih $61,42 \%$ ispitanica i $38,57 \%$ ispitanika. Prosječna starosna dob tih učenika bila je 13 godina. U svakoj školi odabrani su predstavnici razreda iz različitih odjela, kao i učenici različitog uspjeha (odlični, vrlo dobri, dobri, dovoljni) iz predmeta materinski jezik i književnost.

Tablica 1

\section{Tehnika i instrument istraživanja}

Tijekom istraživanja koristila se tehnika anketiranja, a od instrumenata anketni upitnik, koji smo u pisanom obliku dostavili ispitanicima, uz instrukcije za popunjavanje. Anketni upitnik šireg istraživanja sastojao od deset pitanja, od kojih su dva bila otvorenog tipa. Ostala pitanja pripadala su kategoriji pitanja višestrukog izbora, pri čemu je kod pet pitanja bilo moguće dopunjavanje ili dopisivanja vlastitog stava. Navedenu mogućnost iskoristio je malen broj ispitanika.

Za temu naše rasprave izdvojili smo i analizirali odgovore na tri pitanja višestrukog izbora. Na osnovi analize odgovora na tri izdvojena pitanja nastojali smo utvrditi koliko stvaranje teksta kao aktivnost na uzrastu trećeg ciklusa (sedmi, osmi i deveti 
razred) učenike uopće privlači, tj. kako je oni rangiraju u odnosu na druge aktivnosti koje se odvijaju na satima materinskoga jezika i književnosti, zatim koja aktivnost od ponuđenih učenicima najviše odgovara prilikom pripremanja za izradu pisanoga sastavka, te koje aktivnosti učitelji zaista provode u razredu kao pripremu za njegovu izradu.

\section{Rezultati i rasprava}

Motiviranost učenika za angažiranje na satima jezika i književnosti i njihovo promišljanje o sadržajima koji se usvajaju uvjetovano je, između ostalog, zainteresiranošću za određenu aktivnost. Zato smo, prije svega, istražili koje aktivnosti učenici trećeg ciklusa preferiraju na satima jezika i književnosti. Ponuđene kategorije oni su rangirali kako je prikazano na grafikonu 1.

\section{Grafikon 1}

Čitanje i analizu književnoumjetničkih tekstova većina učenika rangira veoma visoko (44,44\%). S obzirom na prirodu književnoumjetničkog djela i njegovo svojstvo da, kao slojevita tvorevina u kojoj se prepleću emocionalni, fantazijski, asocijativni i misaoni spletovi (Rosandić, 2005), pobuđuje estetski doživljaj, kao i sklonost (ili naviku!) učitelja da se detaljnije bave književnoumjetničkim tekstovima kao, doskora, jedinom vrstom teksta na kojoj se, osim ustaljene analize, razvijala strategija čitanja, razmatrala su se jezična pitanja i savladavalo se gradivo iz područja gramatike i pravopisa - nije neobično da učenici tu aktivnost u velikoj mjeri odvajaju od ostalih.

Neumjetnički tekstovi rangirani su na posljednjem mjestu (0,65\%) iako bi njima, $\mathrm{u}$ skladu s aktualnim programom u Crnoj Gori, trebalo posvetiti priličan broj školskih sati $^{8}$, čime želimo istaći stvarnu mogućnost da učenici razumiju i prepoznaju obilježja i takve jezične upotrebe. To se posebno odnosi na znanstveno-popularne tekstove u kojima se obrađuju zanimljive teme iz područja prirodnih i društvenih znanosti, i čitanjem razvija veoma važna kompetencija učenja. Na osnovi tog podatka možemo

\footnotetext{
${ }^{8}$ Predmetni program namijenjen nastavi materinskog jezika i književnosti u Crnoj Gori sastoji se od dvaju područja: nastave jezika i nastave književnosti. U okviru nastave jezika čitaju se neumjetnički tekstovi različitih vrsta, stvaraju tekstovi po ugledu na one koji se čitaju (usmeno i pisano izražavanje) i proučavaju gramatika i pravopis. Nastava književnosti obuhvaća čitanje i interpretaciju književnoumjetničkih tekstova, stvaranje tekstova po ugledu na one koji se čitaju (usmeno i pisano izražavanje) i usvajanje književnoteorijskih pojmova (u skladu s uzrastom). U prvom razredu nastavi jezika i nastavi književnosti namijenjeno je po $50 \%$ ukupnog broja sati, a od drugog do devetog razreda nastavi jezika namijenjeno je $60 \%$, a nastavi književnosti $40 \%$ od ukupnog broja sati na godišnjoj razini. U programima su jasno istaknuti ciljevi $(2005,2011)$ i ishodi $(2017)$ koji se odnose na korake u razvijanju strategije čitanja neumjetničkih tekstova i navedene su vrste tekstova koje u određenom razredu treba obraditi (npr. šesti razred, obrazovno-odgojni ishod 2: Na kraju učenja učenik će biti sposoban da nakon slušanja $i$ čitanja $i$ analize neumjetničkih tekstova izdvoji ključne pojmove i sa njima povezane važne podatke, klasifikuje ih, uporedi $i$ dopuni, zatim zapamti $i$ koristi u novim situacijama (učenje putem čitanja). Ishodi učenja - tokom učenja učenik će moći da: s razumijevanjem čita i analizira neumjetničke tekstove; odredi osnovne odlike naučno-popularnih tekstova, povezanih sa sadržajima drugih predmetnih područja (opis života vršnjaka, igre, zanata, sporta; opis okoline, života ljudi nekad i sad, događaja u prirodi, biljaka; opis razvoja čovjeka i životinje; opis predmeta, proizvoda, mašina); odredi temu teksta i njegovu namjenu; usmeno i pisano odgovori na nastavnikova pitanja o sadržaju teksta; iz teksta izdvaja zahtijevani podatak; iz teksta izdvaja ključne pojmove i s njima povezane važne podatke i unosi ih u pripremljenu pojmovnu mapu; pojmovi: naučno-popularni tekstovi povezani sa temama iz drugih predmeta.
} 
pretpostaviti da rad na neumjetničkim tekstovima još uvijek nije u dovoljnoj mjeri zaživio u nastavi jezika, iako je iznimno važan za razvoj čitateljske pismenosti u njezinoj cjelovitosti.

Učenici uglavnom daju prednost stvaranju pisanoga teksta (18,30\%), a manjih se broj njih opredjeljuje za stvaranje usmenog teksta (10,46\%). Uzrok tomu može biti upravo favoriziranje pisane jezične proizvodnje od učitelja, čak i u situaciji kada se programom predlaže da se svakoj jezičnoj aktivnosti (slušanju, govorenju, čitanju i pisanju) posveti po $25 \%$ ukupnog broja sati namijenjenih tome predmetu. Pretpostavljamo da takvu odluku učitelji donose upravo zbog kompleksnosti pisane riječi i procjene da je za tu vrstu proizvodnje potrebno mnogo više vremena nego za usmenu. Ne samo učitelji, već i metodičari, uglavnom daju prednost pisanome stvaralaštvu. „Da se kod nas kulturi pisanog izražavanja više poklanja pažnja nego usmenom izražavanju, vidi se i po tome što broj radova koji se bave pisanim izražavanjem daleko nadmašuje broj radova koji se bave usmenim izražavanjem..." (Ilić, 1998, str. 536).

U odnosu na prethodna razmatranja možemo utvrditi da sigurno postoji više razloga za nedovoljno prepoznavanje i razumijevanje važnosti rada na neumjetničkim tekstovima, kao i ravnomjernog razvoja sve četiri jezične komponente. To bi moglo biti važno područje na koje je potrebno usmjeriti neka nova istraživanja.

Osim aktivnosti koje čine okosnicu predmeta ponuđenih upitnikom, učenici su imali mogućnost da, ako žele, dodaju još neku aktivnost koja je njima osobno zanimljiva, a tiče se te nastave. Tu je mogućnost iskoristio veoma malen postotak ispitanika $(0,05 \%)$, a aktivnosti koje su navodili, iako mogu biti dio nastave materinskoga jezika i književnosti, više pripadaju slobodnim aktivnostima, pa ih za ovo istraživanje ne smatramo relevantnim.

Pravopisna i gramatička vježbanja druga su kategorija koju značajan postotak učenika bira kao zanimljivu (26,14\%). Za visoko pozicioniranje tih aktivnosti može biti zaslužna činjenica da konačan zahtjev za svaki pisani rad jest njegova gramatička i pravopisna korektnost.

Sljedeći zadatak odnosio se na izbor one vrsta pripreme koja učeniku-pojedincu najviše odgovara prilikom stvaranja vlastitog teksta. Ponuđeno im je šest aktivnosti od kojih su oni birali jednu.

\section{Grafikon 2}

U ponuđenom odgovoru nije naglašeno o kojoj vrsti teksta se radi, no uspostavimo li vezu s odgovorima na prethodni zadatak, sasvim utemeljeno možemo razmotriti, prije svega, utjecaj književnoumjetničkog teksta na učeničko stvaralaštvo. Dakle, književnoumjetnički tekst kao prototekst mnogo je puta bio i jest motivacija i oslonac umjetničkome stvaranju i polazište novih značenja u međutekstovnom nadovezivanju, nastanku teksta i metateksta $\mathrm{i}$ iskusnim piscima, pa je stoga sasvim očekivano da ga učenici prepoznaju kao važno polazište i podršku za nove kreacije $(23,38 \%)$. 
Čitani tekst u školskoj nastavi oduvijek se koristio kao polazište za učeničku jezičnu proizvodnju, bilo usmenu bilo pisanu. Postoji mnogo načina da književnoumjetnički tekst bude učinkovit stimulans u fazi podučavanja učenika za stvaranje vlastitog teksta, odnosno kreativno pisanje. Pri tome je jako važan način na koji ga mladi čitatelj aktualizira kao višeznačnu tvorevinu, a osobito je važna uloga učitelja u procesu razumijevanja svih njegovih sastavnica. Učitelj ostavlja prostor i za one dijelove koje su učenici sami istaknuli - kao njihov osobni udio i aktivno sudjelovanje u procesu oblikovanja značenja teksta (Grosman, 2010). Osim razumijevanja teksta, važne su i vježbe njegova sažimanja i prepričavanja kako bi se uvježbavali oblici jezičnog izražavanja i uočavala struktura teksta, tj. njegovi osnovni elementi (Bežen i sur., 2012).

Uobičajeno je da se, nakon čitanja i interpretacije određenog djela ili njegova odlomka, učenicima ponudi nekoliko naslova koji se odnose na tematiku djela, njegovo mjesto i posebnosti u odnosu na književnopovijesni i književnoteorijski kontekst i pripadnost. Razmatranja likova i njihovih postupaka, događaja i njihova slijeda i povezanosti, kao i vrijednosti ideja koje se u djelu pronalaze, otvaraju višestruka i zanimljiva polazišta za promišljanje o mnogim životno važnim pitanjima i nedoumicama. Takvi tekstovi ili njihovi dijelovi mogu biti uzor za određeni način izražavanja - deskripcija, naracija, dijalog i sl. Upoznavanje jezika djela, odnosno posebnosti stila svakog stvaratelja osobno, također je važna stavka za razumijevanje sveukupnog utjecaja književnosti na stvaralaštvo učenika. Ne čudi zato što je najveći postotak učenika najviši rang dao upravo toj mogućnosti pripremanja za vlastitu proizvodnju pisanoga teksta.

Za razliku od teksta, proizvode neke druge umjetnosti (slike, filmove), kao i sadržaje drugih predmeta kao polazišta za stvaranje teksta, učenici u najmanjem postotku visoko rangiraju (7,79\%). Očigledno je, međutim, da je i ta vrsta polazišta za stvaranje posebno inspirativna za prikazani postotak učenika, što, kada je individualizacija u pitanju, nije beznačajno.

Značajan postotak učenika (12,99\%) visoko rangira mogućnost razgovora o temi u razredu, a izradu plana teksta preferira svega $8,44 \%$ učenika. Nizak postotak namijenjen izradi plana teksta ne mora značiti da ga učenici smatraju nevažnim, već da u određenom trenutku daju prednost nekim drugim aktivnostima.

Gotovo identičan postotak ističe značaj razgovora o prvoj inačici teksta (14,29\%) i vremena koje stvaratelji imaju na raspolaganju (14,94\%).

Visoko rangirana kategorija $(18,18 \%)$ jest mogućnost izbora naslova teme, čime se učenicima otvara mogućnost da pišu o onoj njezinoj dimenziji o kojoj imaju najviše formiranih stavova, nastalih vlastitim ili posredno stečenim iskustvom (Popović, Novović, 2016).

Mogućnošću da dopišu kategoriju po svom izboru kod tog pitanja učenici se nisu koristili.

Nakon što smo dobili informaciju o tome što im posebno odgovara kada je u pitanju pisanje, željeli smo saznati što se, po njihovoj procjeni, u razredu zaista i događa. Učenici su imali zadatak da ponuđene aktivnosti pripremanja za pisanje 
potvde, negiraju ili ih označe kao povremene (grafikon 3). Sudeći po odgovorima učenika, učitelji provode sve aktivnosti koje smo naveli, pri čemu je provjera i analiza napisanoga i davanje odgovarajućih smjernica $(33,86 \%)$ označena kao najčešća. Ostale aktivnosti zastupljene su u postotcima na sljedeći način: stvaranje teksta o temama o kojima se prethodno razgovaralo (29,61\%), upućivanje u kompoziciju zadatka (21,82\%), vježbanja usklađenosti s potrebama učenika $(24,47 \%)$ i na kraju zajednička izrada plana teksta $(21,12 \%)$. Iako postotci koji pokazuju postojanje određene aktivnosti u nastavi nisu visoki, povoljna okolnost jest što se u zbroju s kategorijom „povremeno" uspostavlja određena ravnoteža u smislu njihova postojanja i nepostojanja.

\section{Grafikon 3}

Smatrali smo da je važno učenike pitati je li jedan od načina pripreme za stvaranje teksta realizacija vježbanja koje oni procjenjuju korisnim, odnosno usuglašenim s vlastitim potrebama. Pitanje je bilo općeg tipa, pa se moglo odnositi na različite vrste vježbi: jezične, stilske i pravopisne, razvijanje sposobnosti za različite oblike izražavanja, oblikovanje zadatka u skladu s osnovnim pravilima i primjena načela ${ }^{9}$ izrade plana teksta u skladu s uzrastom, zatim valjan izbor riječi i pravilno oblikkovane rečenice, oblikovanje i razvoj ulomaka i njihovo funkcionalno povezivanje u tkivo teksta i sl. Učenici procjenjuju da su vježbe koja im učitelji pripremaju usklađene s njihovim potrebama u postotku manjem od jedne trećine (24,47\%), a stajalište da su povremeno usklađene zastupa $15 \%$ učenika. Podatak da $60,53 \%$ učenika procjenjuje da takvih vježbi nema, osim što možemo tumačiti kao da se uopće ne primjenjuju, možemo pretpostaviti da nisu usklađene s potrebama pojedinaca u različitim školama i odjelima. U svakom slučaju, takav rezultat obavezuje na promišljanje kada je u pitanju nastava jezika i književnosti.

Učenici se u sadržaj zadatka, odnosno u temu o kojoj će pisati, uvode različitim motivacijskim postupcima. Takvi postupci obično su usmjereni na razvijanje intrinzične motivacije prema ovladavanju (ili iskazivanju) sadržajem govora (GudeljVelaga, 1990). Razgovorom o temi o kojoj će učenici pisati otkriva se građa potrebna za nastanak teksta i pokreću učeničke emocije, odnosno afektivna dimenzija stvaranja. $U$ pripremnoj fazi stvaranja važno je krenuti od misaonog obuhvaćanja teme, razmotriti što učenik zna u vezi s temom, što bi trebao znati i što želi saznati, gdje da nađe potrebne informacije i građu, te što bi i kako želio o tome pisati (Visinko, 2010). Poznavanje teme, odnosno sadržaja o kojem treba pisati, bilo da se odnosi na učenikov osobni ili društveni život, prirodu i zavičaj ili na pročitani književnoumjetnički tekst (stvaranje metateksta), osnovno je polazište za nastanak učeničkoga sastavka.

Zanimljivo je, stoga, što svega $29,61 \%$ učenika priopćuje da se u njihovoj učionici primjenjuje razgovor o temi prije nego o njoj počnu pisati, $21 \%$ učenika smatra da

\footnotetext{
${ }^{9}$ Tri osnovna načela kojih se treba držati prilikom izrade plana teksta: načelo jedinstva, načelo progresije i načelo ravnomjernosti (Živković, 2001).
} 
se to događa povremeno, a prilično velik postotak (49,39\%) priopćuje da se to u njihovim učionicama ne događa. Uzroci za takvo viđenje učenika mogu biti različiti. Moguće je da se tijekom nastavnoga procesa koji je prethodio pisanju tema tretirala u okviru određenih aktivnosti (npr. analiza djela koje se bavi sličnom temom), pa da se neposredno prije stvaranja doista o njoj nije govorilo, odnosno, po procjeni učitelja nije ni bilo potrebe jer su učenici putem analize djela dobili dovoljno građe za rad na temi. Iako je postotak u zbroju dvije povoljne kategorije 50,61\%, takav odgovor učenika ipak treba, prije svega, zabrinuti učitelje i potaknuti ih da analiziraju svoju praksu i u skladu s tim uspješnost svakog učenika u oblikovanju vlastitog teksta.

Da je dio pripreme za stvaranje teksta upućivanje u kompoziciju njegove izrade, potvrdilo je $21,82 \%$ učenika, njih $59,53 \%$ smatra da takva vrsta pripreme ne postoji, a $18 \%$ ih priopćuje da se o kompoziciji zadatka govori povremeno. S obzirom na to da je u pitanju treći ciklus, može se očekivati da se prije svake izrade zadatka ne mora govoriti o njegovoj osnovnoj kompoziciji, te bi $18 \%$ povremenog upućivanja u kompoziciju mogla biti realna slika učeničkih potreba u osmom i devetom razredu. Naime, oni su već naučili koje cjeline tekst može imati, kako se one oblikuju i grafički obilježavaju, što može biti njihov sadržaj i uloga, kako se oblikuju i razvijaju ulomci kao manje cjeline određene kompozicijske strukture i slično. Potrebe za takvim podsjećanjem $(21,82 \%)$ mogu se najviše odnositi na učenike sedmog razreda, kao najmlađe u grupi, kao i na starije koji određena znanja nisu stekli na odgovarajućoj razini u prethodnim razredima.

No, ako uzmemo u obzir da priprema za pisanje ne mora biti samo neposredna aktivnost, odnosno ona koja prethodi samoj aktivnosti pisanja - već kontinuirano vježbanje, onda ga je neophodno redovito provoditi, posebno u osnovnoj školi. Osim osnovne kompozicijske strukture teksta (uvod, razrada, zaključak), dobro je vježbati i raspoređivanje građe unutar tih cjelina, posebno razrade. Neposredno povezana s tim umijećem jest izrada plana teksta kojim se, u stvari, strukturira odabrana građa, odnosno planira njezino raspoređivanje.

Zajedničku izradu plana teksta kao načina pripremanja za pisanje prepoznaje 21,12\% učenika, a njih 54,88\% kaže da se takva vrsta pripreme u njihovu razredu ne događa. Da se to događa povremeno, tvrdi $24 \%$ ukupnog broja ispitivanih učenika. Pitanje smo usmjerili na izradu zajedničkog plana kako bismo, u stvari, dobili podatak koliko se na uzrastu trećeg ciklusa taj korak prepušta učenicima. Naime, u procesu stvaranja teksta, bio naslov za sve učenike isti ili ne, na uzrastu o kojem je riječ logično je očekivati da svaki učenik piše individualan plan, tj. plan za vlastiti tekst. Zajednički plan izrađuje se u fazi vježbanja na mlađem školskom uzrastu (dva prethodna ciklusa), pa podatak da se to, kod ispitivane populacije, događa u navedenim postotcima, može značiti da se nastava individualizira u skladu s uzrastom i mogućnostima učenika. Ipak, taj korak u stvaranju teksta uvijek je moguće i potrebno vježbati s određenom grupom učenika, te ga vjerojatno zbog toga oni prepoznaju i kao stalni i kao povremeni način pripremanja za pisanje. 
Koncipiranje vlastitog teksta i pravilno ustrojstvo odabrane građe učenik počinje savladavati još od prvih čitanja i analize tekstova dobrih pisaca koje čita u školi, uočavajući njihovu kompoziciju i stvarajući plan kao kronološki slijed događaja. „Vježbu kompozicije provodimo u redovitoj nastavi svaki put kada određujemo dijelove pročitanomu tekstu" (Visinko, 2010, str. 160). Na osnovi zajedničkog plana učenici mogu lakše izraditi vlastiti, individualni plan za svoj rad. Individualnim planom učenik pokazuje svoj odnos prema prikupljenoj građi, osobno razumijevanje teme i vlastiti pogled na njezinu bit. Smatramo da vježbe za izradu plana treba provoditi kontinuirano u svim uzrastima, no da je inzistiranje na izradi vlastitog plana (također u svim uzrastima) posebno važan korak za mladog stvaratelja. Izrada plana tuđih tekstova svojevrsna je vježba uočavanja njihove kompozicije, ali i savladavanje vještine izrade plana za vlastiti tekst. Cilj je tih vježbi da učenici nauče da u tuđim tekstovima uočavaju redoslijed ideja, njihovu međusobnu priređenost i podređenost, da uočavaju glavnu ideju i njezino razvijanje s pomoću srodnih pojedinosti, da na kraju uočavaju bit pitanja naznačenog temom.

Bitne značajke teksta, koje donekle određuju plan i kompozicija, jesu njegova kohezija i koherencija. Vezama među elementima teksta, gramatičkim ili leksičkim sponama koje rečenice/iskaze ujedinjuju u tekst osigurava se kohezija teksta. Koherencija teksta osim na jezične upućuje i na izvanjezične okolnosti u kojima se određeni iskaz pojavljuje, tj. ona je ono što čitatelj prepoznaje u jezičnoj obavijesti, a nužno je za njezinu interpretaciju (Badurina, 2008).

Ustrojstvo teksta može biti uvjetovano njegovom funkcijom u komunikacijskom činu. Funkcija teksta, zajedno sa situativnim i medijalnim datostima, određuje strukturu teksta, tj. njegovo građenje u tematskom i gramatičkom smislu. Komunikacijska namjera pošiljatelja izražena sredstvima uobičajenim u komunikacijskoj zajednici čini funkciju teksta, jer pošiljatelj šalje određene instrukcije primatelju o tome kako tekst u cjelini treba prihvatiti i shvatiti (Glovacki-Bernardi, 2004).

Procjena i ocjena učeničkih radova rezultira smjernicama za sve učenike, jer se bavi analizom i sintezom uspješnih i manje uspješnih strana svakog zadatka. To je vrlo konkretna aktivnost izravno usmjerena na pisani jezični proizvod svakog učenika, pa nije neobično što je oni prepoznaju i u najvišem postotku $(33,86 \%)$ ističu kao aktivnost pripreme za neka nova pisanja. U procesu vrednovanja i poboljšanja teksta unapređuju se sposobnosti učenika za osvojenu novu razinu govorne kompetencije u pisanoj jezičnoj uporabi. Procesualnost uključuje znanje učenika da ih svaki novi pokušaj približava cilju (Gudelj-Velaga, 1990). Zato ta stavka zavređuje posebnu pažnju i obradu u nekom novom tekstu.

Ostavili smo mogućnost da učenici navedu i neke druge aktivnosti koje nastavnik oblikuje i kojima ih priprema za pisanje. Sudeći po njihovim odgovorima, takve aktivnosti uvodi zanemarivo malen postotak (1,30\%) nastavnika. Možemo pretpostaviti i da ih učenici ne prepoznaju, premda je na uzrastu sedmog, osmog i devetog razreda (treći ciklus) to malo vjerojatno. 
U prilog školskome pisanju koje je, ipak, planirana aktivnost, možemo navesti i stajalište da se ne mora uvijek čekati nadahnuće da bi se pisalo. „Lakše je naći inspiraciju dok pišete nego dok ne pišete, pa stoga ne morate nužno biti nadahnuti da biste sjeli i počeli pisati” (Novaković, 2007, str. 14). Nastajanju i razvoju inspiracije itekako može doprinijeti učitelj koji kontinuirano primjenjuje sva navedena vježbanja i onda kada je pisanje na neki način već počelo.

\section{Zaključak}

Pozicioniranjem pripremnih aktivnosti za pisanje, procjenom njihove relevantnosti u odnosu na sebe same, izborom one koja im najviše odgovara i, na kraju, procjenom u kojoj mjeri u razredu zaista postoje, utvrdili smo da se priprema učenika za pisanu jezičnu proizvodnju u osnovnim školama uglavnom odvija putem različitih i svrsishodnih aktivnosti.

Učenici trećeg ciklusa osnovne škole umjereno su zainteresirani za usmenu i pisanu jezičnu proizvodnju kao aktivnost na satu materinskoga jezika i književnosti. To možemo objasniti kompleksnošću i zahtjevnošću te aktivnosti, pa je to donekle i očekivano. Usmenoj i pisanoj jezičnoj proizvodnji oni pretpostavljaju čitanje i interpretaciju književnoumjetničkih tekstova, pa tu aktivnost visoko pozicioniraju kao posebnu pripremu za stvaranje vlastitoga teksta. Jasno je, stoga, da navedenu aktivnost učitelji ostvaruju, no da je neophodno preispitati se kako i koliko, te na koje je sve načine moguće unaprijediti i tako svrsishodnije iskoristiti tu učeničku motiviranost književnoumjetničkim tekstom u tom području.

Posebna zainteresiranost učenika za aktivnost gramatičkih i pravopisnih vježbanja otvara mogućnost kontinuiranog rada na dostizanju standardnoga jezika u školi i njegovoj korektnoj primjeni u usmenom i pisanom jezičnom izrazu. Iako se, $u$ skladu s programom, gramatički pojmovi i kategorije proučavaju na neumjetničkih tekstovima, oni se, također, prepoznaju i analiziraju i na umjetničkim tekstovima u kojima dobivaju posebna obilježja književnoumjetničkog stila (ekspresivnost, preneseno značenje i sl.).

Kao važan činitelj stvaralaštva učenici prepoznaju određenu slobodu autora u smislu iskazivanja vlastite individualnosti odabirom naslova teme u skladu sa svojim interesima i iskustvima, kao i mogućnošću stvaranja u vremenu duljem od jednoga školskog sata. Učenici pojedinačne konsultacije o napisanom pretpostavljaju grupnim (u razredu), pa je nužno osigurati vrijeme i mogućnost za takvu aktivnost. To pokazuje da je metodičko vođenje tijekom nastanka sastavka od učitelja poželjno i važno na svim uzrastima u osnovnoj školi.

Učenici u velikom postotku navode da stvaranju tekstova ne prethodi razgovor o temi o kojoj će se pisati, što može izravno utjecati kako na sam proces stvaranja (neodgovarajući izbor građe, nefunkcionalan plan teksta i sl.), tako i na konačan proizvod, tj. tekst (moguća odstupanje od teme, neodgovarajuća kompozicijska struktura, raspored glavne i sporednih ideja u tekstu, izbor motiva i njihovo razvijanje, 
likovi, prostor i vrijeme u priči i dr.). Stoga učitelji trebaju analizirati svoju praksu i utvrditi postojanje ili nepostojanje prethodno spomenute aktivnosti, te preduhitriti posljedice pravodobnim planiranjem funkcionalnih vježbi.

U proces dugoročne pripreme za pisanje neophodno je uključiti više različitih vježbi usklađenih s potrebama grupe s kojom učitelj trenutno radi, a koje predlažu metodičari.

Vještinu oblikovanja teksta potrebno je kontinuirano razvijati uz proširivanje znanja o prikupljanju određene građe, vrednovanju i izboru prikupljanih podataka, kao i njihovoj organizaciji, ovisno o uzrastu i individualnim potrebama učenika.

Provjera i analiza napisanog, odnosno procjena i ocjena učeničkih radova, aktivnost je koju učenici prepoznaju kao najzastupljeniju u procesu pripreme za naredna pisanja. S obzirom na to da učenici dobivaju konkretne sugestije za svoj rad, navedenu je aktivnost neophodno primjenjivati i tijekom samog procesa stvaranja (individualne konsultacije). Provjera i analiza napisanoga važna je aktivnost u procesu podučavanja pisanja.

U fokusu narednih istraživanja mogu se naći oblici pripreme za stvaranje teksta koje učenici posebno ističu, kako bi se utvrdio njihov konkretan utjecaj na unapređenje njihove kreativne jezične proizvodnje. Također, istraživanjem treba obuhvatiti aktivnosti za koje učenici tvrde da se u njihovim razredima ne ostvaruju, s obzirom na to da su one elementarne za stjecanje znanja i vještina u području usmenog i pisanog izražavanja učenika. 